\title{
STRATEGIC TARIFF PROTECTION, MARKET CONDUCT, AND GOVERNMENT COMMITMENT LEVELS IN DEVELOPING ECONOMIES
}

Delia Ionascu Krešimir Žigić
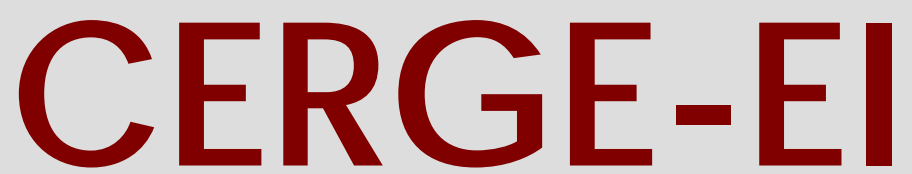

Charles University

CenterforEconomic Research and Graduate Education Academy of Sciences of the Czech Republic

WO RKING PAPER SERIES (ISSN 1211-3298)

Electronic Version 


\title{
Working Paper Series (ISSN 1211-3298)
}

\section{Strategic Tariff Protection, Market Conduct, and Government \\ Commitment Levels in Developing Economies}

\author{
Delia Ionascu \\ Krešimir Žigić
}

CERGE-EI

Prague, March 2005 
ISBN 80-7343-042-8 (Univerzita Karlova v Praze, CERGE)

ISBN 80-7344-031-8 (Národohospodářský ústav AV ČR, Praha) 


\title{
Strategic Tariff Protection, Market Conduct, and Government Commitment Levels in Developing Economies
}

\author{
A Symmetric versus Asymmetric Information Analysis \\ Delia Ionaşcu \\ Copenhagen Business School \\ Krešimir Žigić \\ CERGE-EI, Prague* \\ CEPR, London
}

\begin{abstract}
We analyze a simple "tariffs cum foreign competition" policy targeted at enhancing the competitive position of a domestic, developing country firm that competes with its developed country counterpart on the domestic market and that carries out an innovative (imitative) effort. We evaluate this policy with respect to social welfare, type of oligopoly conduct, information requirement, time consistency, possibility of manipulative behavior and conclude that the most robust policy set-up is that in which the domestic government is unable to precommit to the level of its policy. Finally, we examine this policy, allowing for asymmetric information, and show that the corresponding social welfare may be higher than under perfect information set-up.
\end{abstract}

\begin{abstract}
Abstrakt
Analyzujeme dopady jednoduché politiky „cel a zahraniční konkurence“, zaměřené na podporu konkurenceschopnosti domácích firem sídlících v rozvojové zemi. Domácí firmy inovují (resp.imitují) a utkávají se na místním trhu s podniky z vyspělých zemí. Účinnost uvažovaných opatření je hodnocena vzhledem $\mathrm{k}$ společenskému blahobytu, charakteru oligopolního chování, informační náročnosti, časové konzistenci a možnosti manipulativního chování. Jako nejrobustnější se jeví opatření, při kterém se místní vláda nemůže předem pevně zavázat ke konkrétním krokům. Poté zkoumáme tuto politiku v prostředí asymetrické informace. Závěrem konstatujeme, že v prŕípadě asymetrické informace může být společenský blahobyt vyšší než v prostředí symetrické informace.
\end{abstract}

JEL: F13

Keywords: optimal tariff protection, government non-commitment regime, innovative (imitative) effort, symmetric versus asymmetric information

\footnotetext{
- This research was supported by a grant from the CERGE-EI Foundation under a program of the Global Development Network. Additional funds for grantees in the Balkan countries have been provided by the Austrian Government through WIIW, Vienna. All opinions expressed are those of the author and have not been endorsed by CERGE-EI, WIIW, or the GDN. We would like to thank Pascalis Raimondos-Møller and Christian Schultz for their extremely helpful comments and suggestions on the first draft and Dirk Engelmann and Andrew Austin for helpful comments on the second draft of the paper. Delia wishes to acknowledge the supportive working environment and excellent facilities at the Institute of Economics, University of Copenhagen where she was a Marie Curie fellow.
} 


\section{INTRODUCTION}

The conventional wisdom originating from, for example, the Washington consensus, states that a prerequisite for a developing (or transition) country to achieve a stable growth path is, among other things, to liberalize its trade. However, a recent study by Rodríguez and Rodrik (2001) casts doubt on this previously unchallenged "truth". The authors show that the countries that initially follow a trade protection policy and other import substitution policies, display respectable economic growth per capita for a substantial period of time. They also demonstrate that the subsequent economic crises in some of these countries are not necessarily due to the pursued trade polices, but rather are consequences of bad macro management and adverse external shocks. Rodrik (2001) concludes that trade liberalization is an outcome rather than a precondition for successful economic development.

The above considerations suggest that it might be desirable for a developing economy to protect some of its industries that are believed to have a long-run perspective. Thus, delicate issues here are which industries should be protected and when and how the government may try to assist them. Without entering too much into details of these issues, it could be expected that the selected industry or firm should be one that is capable of narrowing the technological gap vis-à-vis its counterparts in developed countries. This in turn would require that the developing country firm is able to invest efficiently in innovation, or more likely, to closely imitate the advanced technology. Moreover, the initial technological level of the developing country firm should not lag too far behind its developed country counterpart so that it is unable to innovate or directly compete with the developed country's firm given an adequate protection policy.

A variety of policy instruments would protect the domestic market and enhance domestic innovation or imitation. However, as far as the policy choice is concerned, our aim here is rather modest: The criterion for policy selection is not a first-best possible policy mix, but a simple and transparent policy that enhances social welfare.

The standard tools for import protection used in developing countries are tariffs. Tariffs are known to enhance both the innovative effort of the domestic firm and the social welfare $^{1}$ of the country (see, for instance, Reitzes, 1991; Žigić, 2000; Bouët, 2001; and Qiu and Lai, 2001). The optimal level of tariff protection is not likely to be prohibitive, since the

\footnotetext{
${ }^{1}$ The link between tariffs and the innovative (or imitative) activity of the domestic firm is often considered the
} 
presence of the foreign competitor on the market in the form of imports might also be beneficial for consumers, for the domestic firm's incentive to innovate or imitate ${ }^{2}$, and for the state treasury as a source of funds. Yet, foreign firms might "jump over" the tariff by establishing affiliates in the domestic market making, therefore, the tariff policy ineffective (see Motta, 1992). We exclude this case by assuming that it is not optimal for foreign firms to enter the domestic, developing country market due to, for example, prohibitively high entry (sunk) costs in this market. Alternatively we may assume that there is a ban on foreign direct investment. One reason for a ban on foreign direct investment, may, for instance, be that it leads to a crowding out of domestic entrepreneurship in a particular industry (see Das, 2002). Thus in our setup, another "policy tool" that complements tariffs is the competition of the foreign firm in terms of domestic imports. Unlike tariff protection, we treat this former policy as exogenously given.

Although R\&D subsidies are another standard policy tool that enhances the innovative or imitative effort of the domestic firm, the typical developing country usually does not have the financial resources to subsidize R\&D investment. In addition, implementing a subsidy might be troublesome for numerous reasons arising from the high information content required to implement the optimal subsidy to the distorting effects of taxes necessary to finance the subsidy (Bhattacharjea, 1995). Moreover, as Krugman (1989) notes, less developed countries are often unable to commit to future subsidies. Therefore, we discount the possibility of subsidization in our analysis.

Our paper is motivated by the potential importance of this "tariffs cum foreign competition" policy which should enable developing economies to start the catch-up process for those of its industries that exhibit the greatest comparative advantage. We analyze plausible variants of the above policy set-up in terms of social welfare generated, and in terms of the informational requirements for their implementation. We also check whether these policies are prone to time consistency problems and the strategic behavior (manipulation) of the domestic firm. We then compare the polices with free trade and with other relevant benchmark polices, like the hypothetical case in which the domestic government can set the domestic firm's innovative level in addition to setting the tariff.

The "plausible variants" of our trade policy arise due to several factors. The first and

\footnotetext{
core of the infant industry argument.

2 Žigić (2000) shows that the incentives to innovate in a duopoly are higher than in a monopoly in the absence of unilateral R\&D spillovers from the innovative firm to the receiving firm.
} 
the most familiar of these is that the market under consideration is likely to be oligopolistic. In practice, it is often the case that there is only one or a few domestic firms in the industry to be protected by the domestic government and a few foreign competitors. As is well known, even in such a seemingly simple framework, both policy implementation and policy conclusions might be rather sensitive to factors like underlying oligopoly conduct (see Eaton and Grossman, 1986). For example, depending on the type of market competition, levying both tax and subsidy can be an optimal trade policy when domestic and foreign firms compete in a third market.

The second source of possible variations in our policy set-up lies in the (in)ability of the domestic government to commit to its policy (see, for instance, Karp and Perloff 1995; Neary and Leahy; 2000, and Žigić, 2003). This idea can be traced to Carmichael's (1987) observation that governments often set the level of their policy instrument only after firms have already chosen the level of some strategic variable. In this context, a domestic firm might influence (or manipulate) the government's policy response through the level of their variable. This strategic behavior of the domestic firm against the local government causes inefficiencies that may lead to lower social welfare compared to the corresponding social welfare under free trade.

The third and last factor that we consider as a potential cause of policy variation stems from asymmetric information between the firms and the government. As Qiu (1994) points out "... it is reasonable to expect that policymakers have less information than firms concerning production and markets" (p 334). Unlike the majority of existing literature on asymmetric information in strategic trade which assumes cost or demand parameter uncertainty (Qui, 1994; Grossman and Maggi, 1998; Maggi 1999; Bhattacharjea, 2002, among others), we focus here on the particular information asymmetry that arises from the government's uncertainty about the mode of competition (Maggi, 1996 and Ionaşcu and Žigić, 2001). ${ }^{3}$ The relevance of such uncertainty is caused by the fact that the optimal intervention policy might vary with the type of market conduct. If the domestic government

\footnotetext{
${ }^{3}$ Klemperer and Meyer (1986) and Maggi (1996) point out that the type of market competition might be endogenously determined by the nature and severity of demand uncertainty and by the perceived costs of expanding production above the installed capacities, respectively. In principle, by analyzing these factors the government can infer the nature of market competition. Yet, these factors are difficult to measure as they are of a subjective nature. Even when these difficulties can be surpassed and an adequate measure can be computed, a government from a less industrialized country might lack the necessary resources or might be unwilling to cover the costs of gathering the necessary information. In addition, when the marginal cost is constant, the presence of
} 
does not have full information on the type of market conduct it might set a suboptimal trade instrument that could lead to a lower social welfare than the laissez faire level (Ionaşcu and Žigić, 2001).

In modeling the above set-up, we rely on a multistage game where we allow for strategic investment in technology catch-up by the domestic firms that may exhibit the features of industries in developing countries. This investment may take the form of technological upgrading or costly imitation undertaken by the domestic firms in order to acquire the developed country's technology. We consider two polar types of market conduct (Cournot versus Bertrand), and two different timings of government intervention (before investment in technological upgrading occurs and after it). With this model, we test the robustness and the informational requirement across different competition types, as well as different government commitment levels. Moreover, since strategic policies are often criticized for their sensitivity to the type of market competition, we assess how the presence of information asymmetry may affect domestic social welfare. We consider a set-up with asymmetric information in which firms are fully informed about the type of market conduct while the domestic government may only hold some rational beliefs about it.

It is important to stress at the outset that our approach is distinct from the "infant industry protection" analysis. The latter is explicitly concerned with the economic consequences of trade liberalization, or the removal of the tariff barriers about to take place in a specific time horizon (see infant industry papers like Wright, 1995; Leahy and Neary, 1999; Miravete, 2001). In our approach, the issue of removing tariff barriers is beyond the scope of the analysis. We assume that the protection lasts "for a substantial period of time", as Rodrik (2001) has demonstrated, and that if trade liberalization is ever to happen, it would take place during an uncertain, very long period so that the protected firms do not take this into account in their economic calculations.

Furthermore, our analysis is linked to the work of Bhattacharjea (1995) who also analyses tariff policy on the domestic market in the context of developing countries. $\mathrm{He}$ comes to the conclusion that tariffs are robust in different market conducts, and that the informational requirement necessary for identifying their optimal level is not too large compared with, say, investment or output subsidies. In addition, the agency problem does not arise in Bhattacharjea's analysis. However, he considers neither prior strategic R\&D 
investment by firms nor the assumption of possible information asymmetries. Furthermore, he does not analyze the situation when the government can commit in advance to its policies.

Bhattacharjea's result, in which tariffs are robust instruments with respect to the market competition type, carries over fully in our more complex set-up. In addition, we prove that these results hold for different government commitment levels. Regardless of the government's ability to commit to its policy and regardless of the type of market conduct, the foreign rent extraction effect, the reduction in domestic oligopoly distortion effect, and the beneficial effect on domestic innovative (imitation) activity, are strong enough to justify a positive tariff, so that social welfare under protection is always higher than under free trade.

The presence of asymmetric information might have a beneficial effect on domestic social welfare in our set-up. In the first case, in which the government is assumed to be unable to update its prior beliefs about the type of market conduct, a non-committed domestic government will in some cases choose tariff levels that are higher than the symmetric information tariffs and thus generate higher social welfare than in the case of symmetric information. In the second case, where information is asymmetric, the government is allowed to update its beliefs after it observes the firm's R\&D effort. Since the firm with a Cournot conduct may have an incentive to signal its type and differentiate itself from the Bertrand firm, it would invest more in $\mathrm{R} \& \mathrm{D}$, possibly generating higher social welfare as compared to the corresponding perfect information case.

With regard to the information requirements for the implementation of the optimal policy, the information burden in the case of the government commitment regime is higher compared to the non-commitment case, and is, in addition, prone to the manipulative behavior of the domestic firm. The committed government sets the tariff level to enhance domestic innovation effort and needs to know the domestic technology and production parameters.

The remainder of the paper is organized in seven sections. In the second section, we define the model that is followed by a description of the "first-best" optimal R\&D and tariff protection choice. Sections four, five, and six establish the equilibria in the government "noncommitment" regime, free trade and the government "commitment" regime, respectively. In chapter seven, we introduce asymmetric information concerning the competition type. The last section summarizes the main findings of the paper. 


\section{THE ModeL}

We focus on the domestic country. We assume that in this country three different goods are consumed. Two of them are differentiated products produced in an oligopolistic sector while the third one, the numeraire, is produced domestically in a competitive sector. The first two varieties are supplied by a domestic and a foreign firm that compete either in prices or in quantities in the domestic country. ${ }^{4}$

Domestic consumers are of the same type and their preferences are continuously and uniformly distributed on the unit interval. In addition, we assume that the representative consumer has a separable utility function, linear in the numeraire good. Thus, there is no income effect on the consumers' consumption of differentiated goods. The representative consumer's maximization problem can be written as

$$
\max _{q^{d}, q^{f}}\left\{U\left(q^{d}, q^{f}\right)-p^{d} q^{d}-p^{f} q^{f}\right\}
$$

( $q^{d}$ and $q^{f}$ denote the consumption of differentiated goods produced by the domestic and the foreign firm, respectively, $p^{d}$ and $p^{f}$ are their respective prices, and $U(\cdot, \cdot)$ stands for the consumer's subutility function of consuming the differentiated goods). Moreover,

$$
C S\left(q^{d}, q^{f}, p^{d}, p^{f}\right)=U\left(q^{d}, q^{f}\right)-p^{d} q^{d}-p^{f} q^{f}
$$

is an exact measure of consumers' surplus. Like Singh and Vives (1984), we assume that $U(\cdot, \cdot)$ is a quadratic and strictly concave function given by

$$
U\left(q^{d}, q^{f}\right)=\alpha_{d} q^{d}+\alpha_{f} q^{f}-\frac{1}{2}\left[\beta_{d}\left(q^{d}\right)^{2}+2 \gamma q^{d} q^{f}+\beta_{f}\left(q^{f}\right)^{2}\right]
$$

where $\alpha_{i}>0$. From the strict concavity assumption, it follows that $\beta_{i}>0$ and $\beta_{d} \beta_{f}-\gamma^{2}>0$, for $i$ $=d, f$. Also, to ensure the existence of direct demands we assume that $\alpha_{i} \beta_{j}-\alpha_{j} \gamma>0$ for $i \neq j, i$ $=d, f$. The parameter $\gamma$ quantifies the type and the degree of differentiation between the two varieties. We assume that the two differentiated varieties are substitutes, so $\gamma \geq 0$.

Following the utility maximization problem the inverse demands are linear and are given by

$$
\begin{aligned}
& p^{d}\left(q^{d}, q^{f}\right)=\alpha_{d}-\beta_{d} q^{d}-\gamma q^{f} \\
& p^{f}\left(q^{d}, q^{f}\right)=\alpha_{f}-\beta_{f} q^{f}-\gamma q^{d} .
\end{aligned}
$$

The original technology of the domestic firm lags behind that of the foreign firm. It

\footnotetext{
${ }^{4} \mathrm{We}$ assume that there is no consumption of the differentiated variety in the foreign country. Alternatively, we can assume that the foreign and the domestic market are segmented.
} 
requires a pre-innovation unit cost of $c$, while the corresponding value for the foreign firm, $\mathrm{c}_{f}$, is lower than $c$ and, for simplicity, is set to zero. To catch up with its rival before facing its competitor in the market the domestic firm engages in process $R \& D$ activities. The decrease in marginal cost due to the innovative effort is denoted by $x$. To obtain an $x(\leq c)$ decline in the unit production cost, the domestic firm has to incur $k \cdot i(x)$ costs, where $i(0)=0, i^{\prime}(x) \geq 0$, and $i^{\prime \prime}(x) \geq 0$, for any $x$ on $[0, c]$. Any innovative effort aiming to decrease the marginal cost below 0 brings the $\mathrm{R} \& \mathrm{D}$ costs to infinity. The parameter $k$ describes the efficiency of the innovative process and so $k$ can be viewed as the indicator of the domestic's firm ability to narrow the technological gap. We further assume that the technology of the foreign firm is mature enough and does not require any R\&D efforts.

The government in the domestic country considers raising the innovative activities of the local firm and social welfare by introducing a tariff. We assume a benevolent government that cares about all the agents in the domestic economy (consumers, the local producer, and its own revenue). In what follows, the variable $t$ stands for the specific tariff level ( $t=0$ when there is no tariff protection).

Depending on the government's ability to commit to its policy, we consider two related three-stage games. If the government can commit in advance, the actual level of tariff is set before the domestic firm sets its innovate efforts. Then, in the first stage of the game, the domestic government announces the tariff protection level ( 0 if there is no intervention). In the second stage, the domestic firm invests in R\&D. Finally, in the third stage, the two firms meet in the domestic market where they compete either in prices or in quantities. We refer to this game as the government "commitment" case. When the optimal tariff is chosen after the $\mathrm{R} \& \mathrm{D}$ is already in place but before competition takes place, the first and the second stages of the game are reversed. So, first the domestic firm chooses its level of innovation, then the domestic government sets the level of tariff protection. At the end, the competition in the market takes place. We call this game the government "non-commitment" case.

Using the above notations, we can write the firms' profits in the domestic market as

$$
\begin{aligned}
& \pi^{d}\left(s^{d}, s^{f} ; x\right)=q^{d}\left[p^{d}-(c-x)\right]-k i(x) \\
& \pi^{f}\left(s^{d}, s^{f} ; t\right)=q^{f}\left[p^{f}-t\right]
\end{aligned}
$$

where $s$ stands for $q$ if the firms compete in quantities and for $p$ when they compete in prices. However, running a separate analysis for the quantity competition and for price competition is arduous, cumbersome and messy. In order to avoid this, we put both the Bertrand and Cournot 
analyses under a common umbrella. Namely, we assume that each firm has an explicit conjecture about its competitor output choice (see e.g. Eaton and Grossman, 1986; Dixit 1988 or Martin, 1993). These conjectures are defined by parameters $v_{d}, v_{f}$ and by means of them we can easily reproduce both the Cournot and Bertrand equilibria since $v_{d}=v_{f}=0$ for Cournot competition and $v_{d}=-\frac{\partial p^{f} / \partial q^{d}}{\partial p^{f} / \partial q^{f}}=-\frac{\gamma}{\beta_{f}}, v_{f}=-\frac{\partial p^{d} / \partial q^{f}}{\partial p^{d} / \partial q^{d}}=-\frac{\gamma}{\beta_{d}}$ for Bertrand competition. We can regard now the last stage of the game as a quantity decision subgame, but depending on the choice of parameters $v_{d}$ and $v_{f}$, we actually get either the Cournot set-up or the Bertrand set-up. ${ }^{5}$ To simplify the notations and the formulas, we set $V_{d}=\beta_{d}+\gamma v_{d}$ and $V_{f}=\beta_{f}+\gamma v_{f}$ (a possible interpretation of $V_{d}$ and $V_{f}$ will be given later). It is straightforward to verify that for both the Bertrand and Cournot conjectures, the property $V_{d} \beta_{f}-V_{f} \beta_{d}=0$ holds.

In what follows we assume that under tariff protection (with or without government commitment), the cost and demand parameters are such that the equilibria are characterized by interior solutions for the product competition stage and levels of innovation higher than zero. Using the above notations, these requirements impose the following constraints on parameters:

$$
\begin{aligned}
& c<\alpha_{d} . \\
& k i^{\prime}(0)<\frac{2 V_{d}\left(V_{f}+\beta_{f}\right)^{2}}{\left[\left(V_{d}+\beta_{d}\right)\left(V_{f}+\beta_{f}\right)-\gamma^{2}\right]^{2}}\left[\alpha_{d}-c-\frac{\gamma}{2 V_{f}+\beta_{f}} \alpha_{f}\right] . \\
& k i^{\prime \prime}(x)>\frac{2 V_{d}\left(V_{f}+\beta_{f}\right)^{2}}{\left[\left(V_{d}+\beta_{d}\right)\left(V_{f}+\beta_{f}\right)-\gamma^{2}\right]^{2}}, \forall x \in(0, c) .
\end{aligned}
$$

The first constraint, (A1), requires the home firm to be a viable monopoly, even without innovating. The second condition, (A2), guarantees R\&D levels larger than zero in the case of tariff intervention (with or without government commitment). It ensures that the domestic firm benefits from its first unit of innovation. The last assumption, (A3), ensures that the second order conditions for the profit maximization problems are satisfied. Note that the assumptions (A2) and (A3) implicitly determine the lower and the upper bound of the R\&D efficiency parameter, $k$, in general. Namely, (A2) requires $k$ to be sufficiently low so that the domestic firm is efficient enough and has a good R\&D potential to benefit from its

\footnotetext{
${ }^{5}$ See Maggi (1996) for a different unified treatment of Bertrand and Cournot competition where choice variables are prices and where the capacity constraint determines the equilibrium outcome (Cournot or Bertrand). Apart from conjectures describing the Bertrand and Cournot equilibria, we do not use here a full-fledge conjectural variation model (see Dixit (1988) on the strengths and limits of this approach).
} 
$\mathrm{R} \& \mathrm{D}$, for its given market size. On the other hand, $k$ in general, needs to have the lower bound for the problem under consideration to be nontrivial. That is, (A3) calls for $k$ high enough for domestic social welfare to be a strictly concave function in $t$.

When necessary, to distinguish both the firms' and government's choices between the two different types of competition, we will use superscript $C$ for variables in Cournot competition and superscript $B$ to denote Bertrand values.

\section{THE "FIRST-BEST” EQUILIBRIUM}

We begin the social welfare analysis by deriving and discussing the hypothetical socially optimal equilibrium in which the government, besides the tariff, would be able to choose directly the level of its firm's innovative (or R\&D) effort. ${ }^{6}$ For convenience, we label this equilibrium the "first-best" optimum ${ }^{7}$. In this case, tariff and innovation levels are chosen at the same time, and the game is solved (like all other games under consideration) backwards in order to find the subgame perfect equilibria. The first order conditions associated with the profit maximization problems are

$$
\begin{aligned}
& p^{d}-(c-x)-V_{d} q^{d}=0 \\
& p^{f}-t-V_{f} q^{f}=0
\end{aligned}
$$

(where $V_{d}$ and $V_{f}$ could be interpreted as the slopes of the perceived inverse demands for the home and foreign firm respectively; see Singh and Vives, 1984). The optimal quantities that solve the system of equations (3) and (3') are given by

$$
\begin{aligned}
& q^{d}(x, t)=\frac{1}{\left(V_{d}+\beta_{d}\right)\left(V_{f}+\beta_{f}\right)-\gamma^{2}}\left[\left(V_{f}+\beta_{f}\right)\left(\alpha_{d}-c+x\right)-\gamma\left(\alpha_{f}-t\right)\right] \\
& q^{f}(x, t)=\frac{1}{\left(V_{d}+\beta_{d}\right)\left(V_{f}+\beta_{f}\right)-\gamma^{2}}\left[\left(V_{d}+\beta_{d}\right)\left(\alpha_{f}-t\right)-\gamma\left(\alpha_{d}-c+x\right)\right] .
\end{aligned}
$$

Taking into account the first order condition (3), the domestic firm's profit (2) can be rewritten as

$$
\pi^{d}(x, t)=V_{d}\left(q^{d}(x, t)\right)^{2}-k i(x)
$$

where $q^{d}(x, t)$ is given by (4).

\footnotetext{
${ }^{6}$ Note that in terms of social welfare this is equivalent to assuming that the government can set an optimal R\&D subsidy (tax).

${ }^{7}$ However, the usage of the term "first-best" is not completely correct here since the true "first-best" policy in our set-up would also involve an output subsidy to correct for oligopoly distortion (see also footnote, 10). Nevertheless, we use the term "first-best" to distinguish it from polices where only tariff is available.
} 
We can now solve for the "first-best" values of R\&D and tariff. Since we assumed that the domestic government cares about all the agents in the economy, its social welfare function is given by

$$
W=C S+\pi^{d}+t q^{f}=U\left(q^{d}, q^{f}\right)-\left[(c-x) q^{d}+k i(x)\right]-\left[p^{f}-t\right] q^{f} .
$$

It follows that an infinitesimal change in the subgame perfect equilibrium produces a social welfare effect

$$
d W=\left(p^{d}-c+x\right) d q^{d}-q^{f} d\left(p^{f}-t\right)+t d q^{f}+\left(q^{d}-k i^{\prime}(x)\right) d x
$$

that is a combination of four different effects: (i) a domestic oligopoly distortion effect: From a social point of view, domestic output produced in equilibrium is too small since its marginal utility ( $\left.p^{d} d q^{d}\right)$ exceeds its marginal cost $\left((c-x) d q^{d}\right)$; (ii) a positive terms of trade effect: A tariff causes the net foreign price $\left(p^{f}-t\right)$ to fall when the demand function is linear; (iii) a volume of trade effect: A decrease in the quantity of imported goods has a negative impact on the tariff revenue; (iv) a cost reduction effect: An increase in innovation has a positive effect on the domestic firm's profit. While the first three effects were present in Dixit (1988) and Cheng $(1988)^{8}$, the fourth effect is new and is specific to this set-up with R\&D innovation.

Using the foreign firm's first order condition (3') we can rewrite the total social welfare effect (7) as

$$
d W=\left(p^{d}-c+x\right) d q^{d}-\left[V_{f} q^{f}-t\right] d q^{f}+\left(q^{d}-k i^{\prime}(x)\right) d x .
$$

When we employ in (8) the home firm's first order condition (3) and the inverse demand (1) we obtain

$$
d W=\left(V_{d} q^{d}+V_{f} \frac{V_{d}+\beta_{d}}{\gamma} q^{f}-\frac{V_{d}+\beta_{d}}{\gamma} t\right) d q^{d}+\left(q^{d}-k i^{\prime}(x)-V_{f} \frac{1}{\gamma} q^{f}+\frac{1}{\gamma} t\right) d x .
$$

From (4) and (4') we see that $q^{d}$ can be expressed independently of $x$ as a function of $q^{f}, t$, and the model's parameters. Thus, $q^{d}$ and $x$ are linearly independent variables. In this situation, to have $d W=0$ for arbitrary values of $d q^{d}$ and $d x$ (not both zero) as the social welfare maximization problem requires, it is necessary and sufficient that the values of both parentheses in (9) equal zero.

When we equate the first parenthesis of formula (9) to zero, that is

\footnotetext{
${ }^{8}$ Cheng (1988) calls the third effect an "import consumption distortion effect". See a more detailed description of these first three effects in this paper.
} 


$$
V_{d} q^{d}+V_{f} \frac{V_{d}+\beta_{d}}{\gamma} q^{f}-\frac{V_{d}+\beta_{d}}{\gamma} t=0
$$

we obtain the "first-best" value of tariff

$$
t_{s o}=V_{f} q^{f}+\gamma \frac{V_{d}}{V_{d}+\beta_{d}} q^{d} .
$$

The optimal tariff serves to extract foreign duopoly rents and to eliminate part of the domestic oligopoly distortion by enhancing the home firm's market share. ${ }^{9}$ This latter role, however, could be more efficiently performed by an output subsidy/tax, and therefore, an optimal policy mix would also incorporate an output policy (see Dixit, 1988). ${ }^{10}$

By replacing in the optimal tariff formula (11) the actual quantities $q^{d}$ and $q^{f}$ from formulas (4) and (4'), and by exploiting the fact that $V_{d} \beta_{f}-V_{f} \beta_{d}=0$ for both Bertrand and Cournot conjectures, we obtain a simplified form of this tariff

$$
t_{s o}=\frac{\alpha_{f}}{2+\frac{\beta_{f}}{V_{f}}} \cdot{ }^{11}
$$

The level of this tariff depends only on the intercept of the foreign inverse demand function and on the ratio between the foreign firm's elasticity of inverse demand and its perceived elasticity. It does not depend on the innovation level $x$. Consequently, social welfare (6) seen as a function of $t$ and $x$ is separable with respect to these two variables.

To find the "first-best" innovation level, we equate the second parenthesis of formula (9) with zero, and we obtain

$$
q^{d}-k i^{\prime}\left(x_{s o}\right)-V_{f} \frac{1}{\gamma} q^{f}+\frac{1}{\gamma} t=0,
$$

alternatively, in the case of corner solutions for the R\&D level, $d x=0$.

The government would use the innovation effort of its firm as an imperfect substitute for the output subsidy. That is, part of the domestic oligopoly distortion would be reduced through higher R\&D investment, since a higher level of innovation would bring about a higher domestic production, thereby reducing the gap between the price and the marginal

\footnotetext{
${ }^{9}$ When tariff and innovation levels are chosen simultaneously (as is the case in this section) a change in tariff has a direct impact on $q^{d}, q^{f}$, and $p^{f}-t$ but not on $x$, so only the first three effects from (7) are present.

${ }^{10}$ Actually in this set-up which includes an R\&D choice, a combination of three policies forms the first-best policy: a tariff, an output subsidy (tax for price competition), and an R\&D subsidy.

${ }^{11}$ Based on Dixit (1988), more parameters would be included in formula (12) (Dixit, 1988 uses slightly different notations than ours). However, for all conjectures that verify $V_{d} \beta_{f}-V_{f} \beta_{d}=0$, thus for all conjectures for which there is the same ratio between the firms' elasticity of demand and their perceived elasticities, formula (12) holds. In the case of Cournot conjectures, this was previously noted by Bhattacharjea (1995).
} 
cost. $^{12}$ The government then faces a trade-off between the social benefits from a reduced domestic oligopoly distortion and the associated costs (the costs of innovation and the negative impact on the volume of trade). Therefore, when we employ the "first-best" tariff (11) in (13) we obtain

$$
k i^{\prime}\left(x_{s o}\right)=q^{d}\left(x_{s o}, t_{s o}\right) \frac{2 V_{d}+\beta_{d}}{V_{d}+\beta_{d}} \cdot{ }^{13}
$$

As we said, the discussion of the "first-best" social welfare and its accompanied optimal values (like unit cost reduction and tariffs), in the hypothetical case when the domestic government can directly and simultaneously determine both R\&D effort of its firm and specific tariff, will serve as a benchmark for the comparison with the social welfare and the corresponding optimal values in "more realistic" equilibria. These more realistic equilibria are those in which the government is constrained only to the choice of tariffs or free trade. In the subsequent analysis we will continue to refer to $t_{s o}$ and $x_{s o}$ as "first-best" socially optimal values and compare them with the corresponding values of $t$ and $x$ in situations when the firm itself chooses unit cost reduction and the government only sets the tariff (either after or before the strategic choice of the domestic firm).

\section{THE “NON-COMMITTED” DOMESTIC GOVERNMENT}

We first analyze the situation where the domestic government cannot commit in advance to its policy. If a tariff is introduced, its level is chosen only after the local firm has already selected the level of its R\&D effort.

\subsection{Tariff policy}

The level of the optimal tariff maximizes the social welfare function (6). As we noticed in the previous section, social welfare as a function of $x$ and $t$ is separable, so the optimal tariff will be equal to the "first-best" value described by (12), namely

$$
t^{*}=t_{s o} .
$$

This is a quite remarkable and somewhat unexpected result. The optimal tariff in a

\footnotetext{
12 However an output subsidy would still enhance the domestic welfare, since it eliminates the domestic oligopoly distortion that persists even at lower marginal costs.

${ }^{13}$ In the case of corner solutions for R\&D investment $(x=c)$, this equality becomes inequality:

$k i^{\prime}\left(x_{s o}\right)<q^{d}\left(x_{s o}, t_{s o}\right)\left(2 V_{d}+\beta_{d}\right) /\left(V_{d}+\beta_{d}\right)$. This will be the case for all the first order conditions for the R\&D level. We derive and prove here all the results considering interior solutions for R\&D. However, all the results
} 
simple set up where the domestic government is not able to commit in advance coincides with the "first-best" tariff. The reason for this is that the optimal tariff does not depend on the innovation effort, since $R \& D$ investment in our set-up affects only the domestic marginal cost, which has no effect on the optimal tariff level. ${ }^{14}$ However, the independence of the optimal policy instrument on domestic R\&D breaks down in the case of subsidies. In a similar set-up but with output subsidies rather than tariffs, we proved that the government's policy depends on the level of $R \& D$ investment and therefore is subject to manipulative behavior from the domestic firm (see Ionaşcu and Žigić, 2001). Another situation where the innovation effort influences the level of the optimal tariff arises when there are spillovers from the innovating to the non-innovating firm (see Žigić, 2003). However, in our set-up, R\&D spillovers from domestic to the foreign firm are clearly not an issue at all.

One should note that, $t^{*}$, is, in fact, a time-consistent tariff (see Goldberg, 1995). This is particularly important in the developing country context, since the governments of such countries often fail to ensure in advance the credibility of their policies (see also Bhattacharjea, 1995, on this issue).

When we replace the values of $V_{f}$ corresponding to the two types of product competition, the optimal tariff in the Cournot competition case is given by

$$
t^{* C}=\frac{\alpha_{f}}{3}
$$

and in the case of Bertrand competition by

$$
t^{* B}=\frac{\alpha_{f}}{3+\frac{\gamma^{2}}{\beta_{d} \beta_{f}-\gamma^{2}}} .
$$

In the case of Cournot competition the policymakers need to know only the market size of the foreign firm, while in the Bertrand case some extra information regarding the sensitivity of prices to demand and the degree of differentiation is required. Nevertheless, since in both cases no information on domestic costs and $R \& D$ investment is required, the agency problem is precluded.

Thus, tariffs as policy instruments prove to be robust and not too demanding in terms of informational requirements and seem to be a good alternative to the first-best policies - a mix of tariffs and output and R\&D subsidies/taxes - so often criticized for their sensitivity to 
market conduct and extensive informational requirements. Nevertheless, there is a greater informational requirement in the Bertrand than in the Cournot type of market interaction. The optimal tariff in Cournot competition is also higher than that in Bertrand. The reason for these differences lies in the role that the domestic tariff performs. The tariff helps to extract rents from the foreign firm, to raise revenue for the domestic treasury and to reduce the consumption distortion induced by the oligopolistic competition. The tariff accounts for the latter effect directly, by enhancing domestic production and, indirectly, through its effect on innovation: Domestic firms expecting that the imports will be subject to a tariff invest more in $\mathrm{R} \& \mathrm{D}$ than under free trade.

The extent to which the tariff protection could be used to extract foreign rents and to reduce the oligopoly distortion is determined by the ratio between the foreign firm's elasticity of inverse demand and its perceived elasticity [see expression (12)], which is in fact a measure of market competitiveness. ${ }^{15}$ When markets are less competitive (a low ratio), as is the case with the Cournot type of market competition, there are more foreign profits to be extracted and there is a higher domestic oligopoly distortion to correct for. Therefore, $t^{*} C_{>}$ $t^{* B}$. To compute the ratio between true and perceived elasticity, more information is needed in the case of price competition. ${ }^{16}$

\subsection{Optimal R\&D effort}

Anticipating that the domestic government will adopt the tariff $t^{*}$, the domestic firm chooses an R\&D level that satisfies the first order condition associated with the maximization problem for the profit (5) evaluated in $t^{*}$, namely

$$
k i^{\prime}\left(x^{*}\right)=2 V_{d} q^{d}\left(x^{*}, t^{*}\right) \frac{\partial q^{d}}{\partial x}\left(x^{*}, t^{*}\right) .
$$

When we replace the first derivative of the quantity $q^{d}$ given by (4) with respect to $x$ in (15) we get

\footnotetext{
${ }^{14}$ In fact, in contrast to the output subsidies, the optimal tariff depends only on the foreign firm's unit cost. If the foreign firm has a $c_{f}$ marginal cost, then the level of the optimal tariff is $\left(\alpha_{f}-c_{f}\right) /\left(2+\beta_{f} / V_{f}\right)$.

${ }^{15}$ A firm producing in a less competitive market perceives its demand as being less elastic to changes in prices than a firm performing in a more competitive environment. Consequently, it produces less at higher prices and accrues higher profits.

${ }^{16}$ One should note that the tariffs' formula remains the same for the most general R\&D investment cost function. The essential restrictions that support these results are the assumptions of only one firm investing in R\&D and constant unit cost.
} 


$$
k i^{\prime}\left(x^{*}\right)=\frac{2 V_{d}\left(V_{f}+\beta_{f}\right)}{\left(V_{d}+\beta_{d}\right)\left(V_{f}+\beta_{f}\right)-\gamma^{2}} q^{d}\left(x^{*}, t^{*}\right) .
$$

From the "first best" point of view, this R\&D investment level is too low. As (A3) holds, the right hand side of the equation (16) and the curve $k i^{\prime}(x)$ have a single crossing property. In addition

$$
t^{*}=t_{s o} \text { and } \frac{2 V_{d}\left(V_{f}+\beta_{f}\right)}{\left(V_{d}+\beta_{d}\right)\left(V_{f}+\beta_{f}\right)-\gamma^{2}}<\frac{2 V_{d}+\beta_{d}}{V_{d}+\beta_{d}},
$$

so $x^{*}$ is smaller than $x_{s o}$ [its implicit formula is given by 14]. Moreover, the Cournot competition yields higher R\&D levels than its Bertrand counterpart does, thus $x^{* B}<x^{*} C$ (see Appendix 1 for a proof).

The important findings from this section are summarized in Proposition 1 below.

\section{Proposition 1}

1. The generated social welfare is below the "first-best" level in both types of market conduct.

2. Both Cournot and Bertrand types of firm under-invest in $R \& D, x$, from the social point of view.

3. The optimal $R \& D$ effort (or marginal cost reduction) in Cournot type of competition, $x^{*}$, always exceeds the optimal $R \& D$ effort in Bertrand type of competition, $x^{* B}$, for any level of product differentiation, $\gamma$, that is, $x^{* C}>x^{*}$.

4. The optimal tariff in Cournot competition is higher than its counterpart in Bertrand competition, that is, $t^{*} C>t^{* B}$.

Thus, regardless of the market conduct, the social welfare is below the "first-best level". The same is true for R\&D investment. Protected by a tariff policy, the domestic firm would find an innovative effort that results in a $x_{s o}$ decrease in marginal cost too expensive since it ignores the fact that at the margin the gains in consumer surplus still offsets the losses in profits and tariff revenue for $x$ levels slightly above $x^{*}$. In addition, the possibility of socially wasteful over-investment in $R \& D$ is precluded by the fact that the optimal tariff in the non-commitment regime does not depend on the level of innovation, $x$, so there is no potentially damaging manipulative behavior of the domestic firm.

The third part of proposition 1 is consistent with the Schumpeterian tradition 
suggesting that more monopolistic markets generate more innovation. The intuition behind these results is that in Cournot competition there are more profits to be gained, and therefore, there are higher returns from a decrease in marginal cost. Technically, the impact of the market conduct on the level of R\&D effort can be quantified by treating $V_{f}$ as a continuous variable that measures the degree of market power. An increase in $V_{f}$ implies a more monopolistic market, and it is easy to show that $\mathrm{d} x * / \mathrm{d} V_{f}>0$ in our set-up (see Appendix 1). Alternatively, the expected ranking between $x^{* C}$ and $x^{* B}$ might be roughly predicated by referring to the famous Fudenberg-Tirole (1984) taxonomy of business strategies, where, in the Bertrand case, the firms competing in prices (being strategic complements) pursue a (socalled) "puppy dog" strategy that asks for "underinvestment" in the strategic variable, which is in our case unit cost reduction, $x$. On the other hand, Cournot competition requires a socalled "top dog" strategy that implies "overinvestment" in the strategic variable (see Tirole, 1991). ${ }^{17}$

The presence of the optimal tariff proves to be crucial in determining the ranking of R\&D investment in the respective market conduct. A higher anticipated tariff in Cournot competition provokes larger investment in R\&D compared with Bertrand competition. As Bester and Petrakis (1993) have shown, in the absence of tariff protection, with high levels of $\gamma$, the ranking is reversed so that $x^{* B}>x^{*}$.

Finally, the higher optimal tariff in the Cournot type of conduct is a consequence of the higher oligopoly distortion in a Cournot setting that requires larger correction.

\section{FREE TRADE}

Free trade equilibrium serves as an important general benchmark for comparison with other policy options. In our case, the comparison of free trade with the "non-commitment" policy regime is of special interest given the critique that the government's inability to precommit to its policy may lead to lower social welfare compared with free trade (see, for instance, Karp and Perloff, 1995; Grossman and Maggi, 1998; Neary and Leahy, 2000; Ionaşcu and Žigić, 2001).

If the domestic government commits to free trade, the level of R\&D investment maximizes the profits given by (5) for a zero tariff. Therefore, the optimal level of innovation

\footnotetext{
${ }^{17}$ However, the notion of "under"- and "over"- investment" in the Fudenberg-Tirole (1984) approach is defined
} 
is implicitly defined as

$$
k i^{\prime}\left(x_{f t}\right)=2 V_{d} q^{d}\left(x_{f t}, 0\right) \frac{\partial q^{d}}{\partial x}\left(x_{f t}, 0\right),
$$

or after appropriate substitution

$$
k i^{\prime}\left(x_{f t}\right)=\frac{2 V_{d}\left(V_{f}+\beta_{f}\right)}{\left(V_{d}+\beta_{d}\right)\left(V_{f}+\beta_{f}\right)-\gamma^{2}} q^{d}\left(x_{f t}, 0\right) .
$$

Regardless of the type of competition in the market, the level of R\&D induced by the anticipated tariff protection is always higher than the optimal level of innovation under free trade. To show this, we first recall from (4) that $q^{d}(x, t)$ is increasing in $t$. Then for $x^{*}$,

$$
k i^{\prime}\left(x^{*}\right)-\frac{2 V_{d}\left(V_{f}+\beta_{f}\right)}{\left(V_{d}+\beta_{d}\right)\left(V_{f}+\beta_{f}\right)-\gamma^{2}} q^{d}\left(x^{*}, 0\right)>0 .
$$

When we take the first derivative with respect to $x$ of the function on the left hand side we get

$$
k i^{\prime \prime}(x)-\frac{2 V_{d}\left(V_{f}+\beta_{f}\right)^{2}}{\left[\left(V_{d}+\beta_{d}\right)\left(V_{f}+\beta_{f}\right)-\gamma^{2}\right]^{2}}>0,
$$

which is positive (due to the assumption A3). Therefore, $x$ should decrease to reach equality again.

The optimal levels of R\&D effort across the different regimes are displayed in Figure 1 RHS $_{\mathrm{so}}, \mathrm{RHS}, \mathrm{RHS}$ ft stand for the right hand side of the equations (14), (16), and (18) respectively]. Note that as $k$ decreases, innovation becomes cheaper, the optimal R\&D levels increase and it is more likely to have corner solutions as shown by the dashed line in Figure 1.

The above results are consistent with the infant industry argument in favor of tariff policies. Indeed, the anticipation of tariff protection enhances the innovative efforts of the domestic firm and therefore positively impacts the domestic firm's production costs.

The above considerations suggest that the domestic firm's profit and social welfare in a non-commitment regime are larger than their counterparts in free trade. The comparison of the relevant equilibrium values in free trade and in the non-commitment regime is given in Proposition 2 below (see Appendix 2 for a proof)

with respect to the non-strategic firm's behavior and not relative to the "first-best" social optimum. 


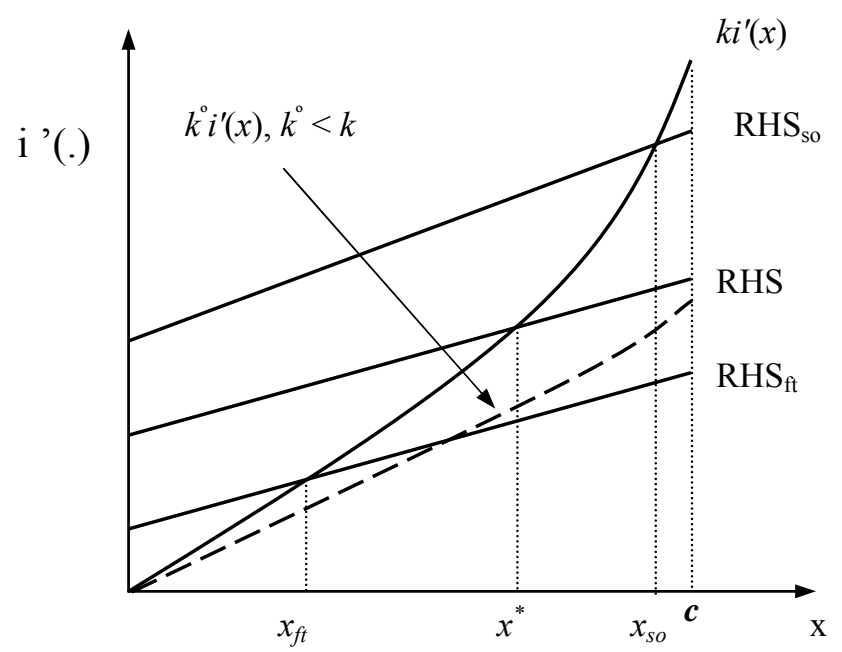

Figure 1. The innovation levels chosen under "first-best", free trade and non-commitment regime

\section{Proposition 2}

Regardless of the type of the market conduct:

1. Social welfare in the non-commitment regime is higher than in the free trade regime.

2. The optimal R\&D effort (or unit cost reduction) in the non-commitment regime, $x^{*}$, is always bigger than the optimal cost reduction under free trade, $x_{f t}$

3. The domestic firm earns a higher profit under such tariff protection than under free trade.

The intuition for the above findings is straightforward; the anticipation of the optimal tariff motivates the domestic firm to enhance its $R \& D$ effort compared to free trade, since the tariff enables the domestic firm to capture a higher market share and gain a higher profit. Thus it has increased incentives to invest in marginal cost reduction. Finally, appearance of the tariff brings revenue to the domestic treasury and the joint impact of increased domestic firm profit and tariff revenue exceeds potential losses in consumer surplus and thus, leads to the increase in social welfare.

\section{THE “COMMITTED” DOMESTIC GOVERNMENT}

When the domestic government is able to commit in advance to the precise value of its policy choice, it announces the level of the tariff protection before the domestic firm invests in $R \& D$. The quantities that the domestic and the foreign firm will produce are given by (4) and (4') respectively. If a tariff is announced in stage one, the domestic firm chooses an innovation level that maximizes (5). Thus, the optimal R\&D choice $x(t)$ for a given $t$, which 
we will denote as $X$, satisfies

$$
k i^{\prime}(X)=\frac{2 V_{d}\left(V_{f}+\beta_{f}\right)}{\left(V_{d}+\beta_{d}\right)\left(V_{f}+\beta_{f}\right)-\gamma^{2}} q^{d}(X, t) .
$$

Regardless of the type of market conduct, the level of innovation increases when the tariff increases. To see this, we take the first derivative of the above equation (19) with respect to $t$ :

$$
\frac{d X}{d t}\left(k i^{\prime \prime}(X)-\frac{2 V_{d}\left(V_{f}+\beta_{f}\right)^{2}}{\left[\left(V_{d}+\beta_{d}\right)\left(V_{f}+\beta_{f}\right)-\gamma^{2}\right]^{2}}\right)=\gamma \frac{2 V_{d}\left(V_{f}+\beta_{f}\right)}{\left[\left(V_{d}+\beta_{d}\right)\left(V_{f}+\beta_{f}\right)-\gamma^{2}\right]^{2}} .
$$

Since the term in brackets is positive due to assumption (A3), and since the sign of the right hand side is the same as the sign of $\gamma$, the impact of an increase in tariff protection on the R\&D level is positive. Therefore, for a given tariff, the R\&D investment under tariff protection is higher than in the case of free trade.

When, for instance, the domestic government chooses $t^{*}$, that is, the optimal tariff in the "non-commitment" regime, equation (19) gives a level of $\mathrm{R} \& \mathrm{D} X\left(t^{*}\right)$ equal to $x^{*}$ (see also equation 16). Thus, in the commitment regime, from the domestic social welfare point of view, the government can do at least as well as without commitment (simply by choosing a tariff equal to $\left.t^{*}\right)$. Consequently, social welfare when the government can commit in advance to its policy is never lower than the optimal social welfare under a non-commitment situation. ${ }^{18}$

The domestic government chooses a level of tariff protection $T^{*}$ that maximizes (6). Since the first order condition (3') still holds, for an infinitesimal change in the Nash equilibrium in quantities, equation (9) is still valid. Plugging it into the domestic firm's first order condition with respect to innovation (19), we obtain

$$
d W=\left(q^{d} V_{d}+\frac{\left(V_{d}+\beta_{d}\right)\left(V_{f} q^{f}-T\right)}{\gamma}+\frac{2 V_{d}\left(V_{f}+\beta_{f}\right)\left(\gamma q^{d}-\gamma k i^{\prime}(X)-\left(V_{f} q^{f}-T\right)\right)}{\gamma k i^{\prime \prime}(X)\left(\left(V_{d}+\beta_{d}\right)\left(V_{f}+\beta_{f}\right)-\gamma^{2}\right)}\right) d x .
$$

The government then chooses a level of tariff $T^{*}$ such that the value of the square brackets is zero. So $T^{*}$ is given by

\footnotetext{
${ }^{18}$ As Žigić (2003) shows, this is generally not true when there are R\&D spillovers from the innovating to the non-innovating firm. However, R\&D spillovers are not a real possibility in our set-up.
} 


$$
\begin{aligned}
T^{*} & =V_{f} q^{f}+\gamma \frac{V_{d}}{V_{d}+\beta_{d}} q^{d}+ \\
& +\gamma \frac{2 V_{d}\left(V_{f}+\beta_{f}\right)\left[q^{d}\left(2 V_{d}+\beta_{d}\right)-k i^{\prime}(X)\left(V_{d}+\beta_{d}\right)\right]}{\left(V_{d}+\beta_{d}\right)\left[k i^{\prime \prime}(X)\left(V_{d}+\beta_{d}\right)\left(\left(V_{d}+\beta_{d}\right)\left(V_{f}+\beta_{f}\right)-\gamma^{2}\right)-2 V_{d}\left(V_{f}+\beta_{f}\right)\right]} .
\end{aligned}
$$

By using $k i^{\prime}(X)$ given by (19), the values for $q^{d}$ and $q^{f}$ given by (4) and (4'), and the fact that for Bertrand and Cournot conjectures $V_{d} \beta_{f}-V_{f} \beta_{d}=0$ we obtain

$$
T^{*}=t^{*}+\gamma \frac{2 \beta_{f}^{2} V_{f}\left[\beta_{d}\left(V_{f}+\beta_{f}\right)^{2}-\gamma^{2}\left(2 V_{f}+\beta_{f}\right)\right] q^{d}}{\left(2 V_{f}+\beta_{f}\right)\left[\beta_{d}\left(V_{f}+\beta_{f}\right)^{2}-\gamma^{2} \beta_{f}\right]\left[k i "(X)\left(\beta_{d}\left(V_{f}+\beta_{f}\right)^{2}-\gamma^{2} \beta_{f}\right)-2 V_{f} \beta_{f}\right]} .
$$

As in the non-commitment case, besides extracting foreign rents, the optimal tariff should correct for domestic oligopoly distortion. Moreover, now that the tariff is chosen before the home firm decides on its innovation level (and no R\&D subsidy is considered), the tariff has an additional role; it has to correct for the level of innovation that, as we saw in the non-commitment case, tends to be sub-optimal. To enhance the innovation level, a higher tariff is required ${ }^{19}$. Hence, the optimal tariff, $T^{*}$, exceeds its corresponding counterpart, $t^{*}$, without government commitment. [It is straightforward to check that the second part in expression (23) is positive.]

The optimal level of R\&D effort, $X^{*}$, calculated from (19) when the tariff, $T^{*}$, given by (23) is considered, is higher than the optimal level of innovation, $x^{*}$, for a non-committed government, but still below the "first-best" optimal level. These results are presented in the following proposition (see the Appendix 3 for a proof).

\footnotetext{
${ }^{19}$ To underline this new role of tariff as a direct instrument for enhancing the innovation level, we look at what happens when the domestic government uses R\&D subsidies to correct for sub-optimal levels of innovation. When the government chooses an R\&D subsidy, $r$, together with the level of tariff protection, the welfare becomes$$
W=C S+\pi^{d}+t q^{f}-r k i(x)=U\left(q^{d}, q^{f}\right)-\left[(c-x) q^{d}+k i(x)\right]-\left[p^{f}-t\right] q^{f} .
$$

Since there is no change in the home and the foreign firm's first order conditions (3) and (3'), the equations (7), (8) and (9) still hold. With an R\&D subsidy in place, $a^{d}$ and $x$ become again independent variables, so once more we get the first order conditions of the welfare maximization problem (commitment case) by setting the values in the parentheses to zero. The first parenthesis $=0$ gives us again formula (10), and consequently formula (12) for the tariff level. The second parenthesis of (9) $=0$ gives (13). When we replace in (13) the formula (12) for the tariff level, and domestic firm's first order condition with respect to R\&D, $k i^{\prime}(x)=2 V_{d} q^{d}\left(V_{f}+\beta_{f}\right) /\left((1-r)\left(\left(V_{d}+\beta_{d}\right)\left(V_{f}+\beta_{f}\right)-\gamma^{2}\right)\right)$, we find that the optimal subsidy is $r=k\left[\beta_{d}-2 V_{d} \gamma^{2} /\left(\left(2 V_{d}+\beta_{d}\right)\left(\left(V_{d}+\beta_{d}\right)\left(V_{f}+\beta_{f}\right)-\gamma^{2}\right)\right)\right]>0$ for both Bertrand and Cournot conjectures.
} 


\section{Proposition 3}

Regardless of the type of the market conduct:

1. The optimal tariff protection in the "commitment" regime is higher than the optimal tariff protection in its "non-commitment" counterpart, that is, $T^{*}>t^{*}$.

2. Consequently, the domestic firm exhibits greater $R \& D$ effort in the "commitment" regime, that is, $X^{*}>x^{*}$ and higher social welfare, that is, $W^{*}{ }_{\text {com }}>W^{*}{ }_{n c o m}$

3. The R\&D efforts in both the "commitment" and "non-commitment" regimes are below the "first-best" value, that is, $x^{*}<X^{*}<x_{s o .}{ }^{20}$

\section{ASSESSMENT OF THE CONSIDERED POLICIES}

Before moving to the policy analysis under asymmetric information, first, we briefly discuss the pros and cons of the three policies with respect to four criteria:

a) the social welfare that they generate;

b) the information requirement for their implementation;

c) the time consistency issue; and

d) the agency problems.

The policies in question are government commitment regime (GCR), government noncommitment regime (GNCR) and free trade (FT). The ranking and the characteristics of the policies are given in Table 1 .

Table 1. Rank (Characteristics) of discussed policies according to various criterions

\begin{tabular}{|l|l|l|l|l|}
\hline PolicylCriterion & Social welfare & $\begin{array}{l}\text { Inform. } \\
\text { requirement }\end{array}$ & Time consistency & Agency problems \\
\hline GCR & 1 (largest) & 3 (high) & $\begin{array}{l}3 \text { (credibility } \\
\text { problem) }\end{array}$ & $\begin{array}{l}3 \text { (prone to agency } \\
\text { problems) }\end{array}$ \\
\hline GNCR & $\begin{array}{l}2 \text { (second- } \\
\text { largest) }\end{array}$ & 2 (low) & 1 (time consistent) & 1 (no agency problem.) \\
\hline FT & 3 (lowest) & 1 (zero) & $\begin{array}{l}3 \text { (credibility } \\
\text { problem) }\end{array}$ & 1 (no agency problem.) \\
\hline
\end{tabular}

Table 1 shows that the only strength of the government commitment regime is that it

\footnotetext{
${ }^{20}$ Although it is not the primary goal of our analysis, comparing the corresponding Cournot and Bertrand equilibria, as we did in a previous section, would be of some interest. However, the expressions are prohibitively complex so that it is not possible to have an analytical comparison leading to close form solutions. Using simulations, we found out that for a specific functional form for the R\&D effort, $f(x)=x^{2} / 2$, and for $\alpha_{d}=\alpha_{f}=1$ and $\beta_{d}=\beta_{f}=1, T^{*^{C}}>T^{* B}$ and, consequently, $X^{*^{C}}>X^{*^{B}}$.
} 
yields the highest social welfare. The information requirement for its implementation is likely to be prohibitively high, and consequently, such a policy is susceptible to all kinds of agency problems between the domestic firm and governments. In addition, the capability of the Southern country government to pre-commit to a given level of tariff is questionable at best, so the time consistency issue may arise.

The government non-commitment regime on the other hand has a rather low information requirement, and is not prone to the agency problems and manipulative behavior of the domestic firm. Moreover, the optimal tariff in this regime is time consistent. The social welfare that it generates is lower than in the commitment regime but higher than in free trade.

Finally, free trade is the most convenient policy as far as the information constraint is concerned, but the worst one from the social welfare point of view. The free trade regime is also not void of time consistency problems. The government's announcement of free trade may not be credible since it would be optimal to intervene via tariff ex post (that is, after innovation takes place).

So the above short discussion suggests that a "middle-of-the-road" policy government non-commitment regime - fairs best in the above qualitative assessments, with two-second ranks (social welfare, information requirement) and two first ranks (time consistency, no manipulation). However, these rankings are probably not enough to proclaim the government non-commitment regime as the champion. If the social welfare that government non-commitment regime generates is only slightly above that of free trade, then it may be better to stick to free trade due to its zero information content requirement if the government can somehow commit to it. On the other hand, if the difference in generated social welfare between the government commitment regime and the government noncommitment regime is "very large", then it might be worth investigating how to overcome the problems associated with the former policy regime. Thus, in addition to a comparative qualitative assessment, we also need a comparative quantitative assessment of the social welfare that the three policies generate. As we show in Appendix 6, this quantitative analysis only reinforces the virtues of the government non-commitment regime. For the purpose of the explicit quantitative analysis, we stick to the specific functional form of the investment function that is assumed quadratic and is given by $i(x)=\frac{1}{2} k x^{2}$. To simplify the calculation, we set $\alpha_{d}=\alpha_{f}=\beta_{d}=\beta_{f}=1$, and $k=2$.

First, comparing the corresponding social welfares in government non-commitment 
regime and free trade, it is clear that optimal tariff has a significant, positive impact on the domestic country's social welfare. The gains from tariff protection are, depending on the model parameters, roughly between 10 and 32 percent in Bertrand competition and between 10 and 57 percent in Cournot competition (see tables 2 and 3 in Appendix 6).

As for the key comparisons between the government commitment regime and the government non-commitment regime, we can see that, regardless of the type of market competition, the percentage loss in social welfare when the government cannot commit in advance to its policy is negligible. The loss ranges between a meager $0.00002 \%$ and an upper rough limit of $1.92 \%$ for Bertrand competition and of $0.14 \%$ for Cournot competition (see tables 4 and 5 in Appendix 6). Our result does not change significantly when we vary parameter $k$.

To conclude, the government non-commitment regime now appears decidedly superior to the other policy options (at least within the assumed specific functional forms). What is even more interesting is that this policy set-up is the prevailing one in the developing world and so the often-expressed worries that the Southern country governments are unable to pre-commit to a policy choice do not seem to be well founded, at least where simple tariff policy is concerned.

\section{MARKET EQUILIBRIUM WITH ASYMMETRIC INFORMATION}

There are many ways in which information asymmetry may appear in the context under consideration. However, much of the critique of strategic trade policy focuses on the government's inability to gather and process all the information necessary for beneficial intervention. Thus, we assume that the player in our setup who lacks relevant information is the domestic government. More specifically, we assume that the government does not know the type of market competition between the domestic and foreign firm. The relevance of such uncertainty is amply described in Eaton and Grossman (1986), although Grossman and Maggi (1998) were the first to call for an explicit analysis of this issue more than a decade later.

Since the government non-commitment regime was the clear champion in the symmetric information setup, we focus on it in this chapter as well. When relevant, we discuss how results change for the government commitment regime.

Even in such a narrowly specified framework, the government's (in)ability to cope 
with the information asymmetry can vary. In the first and standard situation, the government does not know a priori the type of market conduct, but by observing the unit cost reduction of the domestics firm, it may infer the true type of competition. More consequential uncertainty occurs if for some reason the government is unable to learn the type of competition even after the R\&D investment is in place. In what follows, we first analyze the latter type of uncertainty, and then we discuss how results change when the government can infer the true type of competition.

\subsection{Case 1: No updating of government's prior beliefs}

Let us assume that nature chooses the type of market interaction before any firm or government decision takes place. With probability $\eta$ it chooses price competition and with 1$\eta$ it chooses quantity competition. $\eta$ is common knowledge. After that, firms learn the type of competition while the domestic government obtains no extra information. In what follows, we assess the impact of the lack of information on the level of tariff policy and domestic social welfare.

In terms of the timing of the game, we add an additional stage to the game; nature now moves first by choosing the type of market competition. Then, as before, the domestic firm selects its R\&D effort, and thereafter the government sets the level of tariff protection knowing only the probability distribution of the true conduct parameter $V_{d}: \operatorname{Pr}\left(V_{d}{ }^{\mathrm{B}}\right)=\eta$ and $\operatorname{Pr}\left(V_{\mathrm{d}}^{\mathrm{C}}\right)=1-\eta$ where $V_{d}^{\mathrm{B}}$ stands for Bertrand and $V_{d}{ }^{\mathrm{C}}$ for Cournot conduct parameter. In the last stage, the two firms compete in the market.

As was made clear in Proposition 1, the levels of marginal cost reduction might convey information regarding the market type. However, we assume that after the innovation takes place the government does not update its beliefs regarding the type of market conduct. This may be the case when policymakers have bounded rationality, or, alternatively, when it may be too costly for the government to accurately assess the actual levels of $R \& D$ investment.

The domestic government now maximizes

$$
E W=\eta W^{B}+(1-\eta) W^{C}
$$

where $W^{B}$ and $W^{C}$ can be computed from (6) by plugging in it the expressions for the optimal domestic firm's output (4); the first order condition (3); and then the corresponding conjectures. By solving the social welfare maximization problem for a given level of $\mathrm{x}$, we 
find that the optimal tariff level is given by

$$
t^{u}=\frac{\alpha_{f}}{3+\eta \frac{\gamma^{2}}{\beta_{d} \beta_{f}-\gamma^{2}}} .
$$

It is easy to verify that as $\eta$ decreases from 1 to $0, t^{u}$ increases from $t^{* B}$ to $t^{*} C$.

\section{Proposition 4.}

1. If Bertrand conduct is the true type of competition, then for a "high enough" prior probability $\eta$, intervention through an optimal tariff under uncertainty, $t^{u}$, raises the social welfare level above that of its symmetric information counterpart.

2. If Cournot conduct is the true type of competition, the intervention through an optimal tariff under uncertainty, $t^{u}$, results in social welfare higher than under free trade, but lower than that under intervention with symmetric information.

The complete proof appears in Appendix 5.

When Cournot is true market competition, the level of tariff protection, $t^{u}$, is always lower than the optimal tariff with symmetric information $\left(t^{*}{ }^{C}>t^{u}\right)$, and therefore, social welfare under symmetric information is always higher than the social welfare under incomplete information. However, since social welfare is increasing in tariff in the interval [0, $t^{*} C$ ), the optimal protection, $t^{u}$, still generates higher social welfare than free trade.

In the case of Bertrand competition, the presence of uncertainty induces the domestic firm to anticipate levels of tariff protection higher than $t^{* B}$ but lower than $t^{*} C$. Since, as we saw in Section 6, any increase in the tariff protection level towards $T^{* B}$ enhances the social welfare for high enough levels of $\eta$, the expected level of tariff protection will drive innovation and domestic social welfare upward to levels that are higher than the symmetric information social welfare with intervention (see Appendix 5). However, as products become more homogenous and at the same time, the government holds inaccurate beliefs about the true market conduct (that is, $\eta$ tends to zero), social welfare under uncertainty may decrease to levels lower than both the complete information level with intervention and the free trade level with complete information. As the market becomes highly competitive the drop in profit is drastic, and a high tariff close to the Cournot optimal tariff only distorts consumption without bringing sufficient gains from the added innovation (see Appendix 5).

Thus, if the domestic firm does not try to signal the true type of competition in the 
market, and the tariff is set only after the R\&D phase, the presence of uncertainty might enhance the social welfare level above the social welfare with symmetric information and government intervention. This result does not hold in the case of a committed government. When the government is able to commit to its policy before the local firm engages in innovative activities, with or without symmetric information, the government can "credibly" set any tariff above zero. Therefore, the presence of uncertainty does not alter the set of feasible tariffs. As a result, any departure from the optimal tariff level with symmetric information, $T^{*}$, reduces social welfare. Unlike the non-commitment case, the presence of uncertainty here always has an adverse effect on the domestic country's social welfare.

\subsection{Case 2: Signaling}

Up to now we have assumed that the domestic government was not in a position to distinguish between Cournot and Bertrand types of conduct. However, the fact that the Cournot firm always invests more in R\&D than the Bertrand firm (see Proposition 1), means that the level of cost reduction, $x$, could be used by the government to infer the true type of competition in the market. The problem is that the Bertrand firm might try to mimic the behavior of a Cournot firm by choosing a higher cost reduction than under the symmetric information scenario to induce a higher tariff. This, in turn, may force the Cournot firm to invest more in marginal cost reduction than under symmetric information in order to signal its type.

The aim of this section is to briefly discuss the situations (conditions) under which the domestic government can distinguish between the two polar types of market competition.

In order to induce the higher tariff, $t^{*} C$, rather than the low tariff, $t^{* B}$, a Bertrand firm might have an incentive to mimic the behavior of a Cournot firm by choosing cost reduction, $x^{*}$. This would be the case if

$$
\pi^{B}\left(x^{* B}, t^{* B}\right)<\pi^{B}\left(x^{*}, t^{*} C\right) .
$$

When the above condition holds, to induce the government to implement a high tariff, a Cournot firm would have to signal its type by investing more than $i\left(x^{*} C\right)$ in R\&D. Since this differentiation action is costly, the Cournot firm will signal its type only if there is some decrease in marginal cost, $\tilde{x}$, high enough to deter the Bertrand firms to opt for the same investment level, that is,

$$
\pi^{B}\left(x^{{ }^{B} B}, t^{* B}\right) \geq \pi^{B}\left(\widetilde{x}, t^{C}(\widetilde{x})\right),
$$


but, at the same time, this decrease in marginal cost must still be low enough that the firm competing à la Cournot would be better off by revealing its type through signaling than by being perceived as a Bertrand firm

$$
\pi^{C}\left(\tilde{x}, t^{C}(\tilde{x})\right) \geq \max _{x} \pi^{C}\left(x, t^{B}(x)\right)
$$

where $t^{* C}(x)=\arg \max _{t} W^{C}(x, t)$ and $t^{* B}(x)=\arg \max _{t} W^{B}(x, t)$.

The conditions (26), (27), and (27') define the pair of investment levels $\left(x^{* B}, \tilde{x}\right)$ that form a separating equilibrium given the appropriate government beliefs.

As in the previous section, we assume that the prior probabilities of the Bertrand and Cournot types of conduct are given by: $\operatorname{Pr}\left(V_{f}^{\mathrm{B}}\right)=\eta$ and $\operatorname{Pr}\left(V_{f}^{\mathrm{C}}\right)=1-\eta$. We assume that the government's out-of-equilibrium beliefs are such that any $x$ other than $\tilde{x}$ indicates that the firm is of the Bertrand type, or more formally:

\section{$\{\forall x \geq \tilde{x}$ - Cournot type of competition \\ $\forall x<\tilde{x}$ - Bertrand type of competition}

These beliefs support the largest possible set of separating equilibria. Moreover, the government's prior probability distribution and its subsequent updates are assumed to be common knowledge.

As Bhattacharjea (2002) points out, it is usually very difficult to solve analytically for these conditions, and such a task "ultimately relies on numerical simulations to demonstrate the existence and social welfare properties of signaling equilibria, even with linear demands and constant costs" (p. 124). Since our set-up is no exception to this observation, we also choose a numerical simulation, the results of which are summarized below. We assume that the $\mathrm{R} \& \mathrm{D}$ cost function is quadratic and is given by $i(x)=x^{2} / 2$.

In order to characterize the "signaling" separating equilibrium, we first identify the ranges of parameters $c, k$, and $\gamma$ for which it is profitable for a Bertrand firm to imitate the behavior of a Cournot firm by investing $i\left(x^{*}{ }^{C}\right)$ in R\&D so that the condition (26) holds. Our simulations show that for most of the parameter space, a Bertrand firm is better off when it mimics the behavior of a Cournot firm. Only when the level of unit cost $c$ is almost as high as the highest level of $c$ that can still sustain a duopoly structure (see assumption (A2)), the cost of innovation $k$ is very low, and the level of product differentiation is neither very low nor very high $\left(\gamma\right.$ in the $(0.2,0.7)$ range), will a Bertrand firm invest $i\left(x^{* B}\right)$ rather than $i\left(x^{*}\right)^{21}$.

\footnotetext{
${ }^{21}$ Under this parameter constellation, condition (26) does not hold, so a trivial, "non-signaling“" separating equilibrium exists which coincides with the equilibrium under symmetric information discussed in section 4 .
} 
As for the remaining conditions (27) and (27'), they require that the initial marginal cost $c$ be "high enough" for the signaling to be effective. If, on the contrary, the marginal cost is low, the gap between $x^{* B}$ and $x^{*} C$ is small and a Cournot firm has less room for increasing its innovation for signaling purposes. Therefore, it is advantageous for a Bertrand firm to pretend to be a Cournot firm, even if it chooses R\&D levels that bring the marginal cost down to zero.

Given "high enough" marginal costs, $c$, a high level of product differentiation ( $\gamma$ low) increases the likelihood of the existence of a separating equilibrium. If products are highly differentiated, then, on one hand the gap between $x^{{ }^{*} B}$ and $x^{{ }^{*} C}$ is relatively small, as both Cournot and Bertrand firms act almost like monopolists so the mimicking is not too costly. On the other hand, and more importantly, having an almost monopolistic position, the Bertrand firm has much less need for an increase in protection, so even a relatively small deviation from its optimal choice under perfect information may not pay off.

Much like in the no signaling case, the level of social welfare might be higher under asymmetric information than under symmetric information provided that a separating equilibrium exists. This is at least the case when products are highly differentiated. As we have just discussed, when products are not alike, the Bertrand firm has low incentives for increased protection, so the signaling behavior of a Cournot firm results in a mild increase in the innovation level beyond $x^{*}$. As we know from proposition 1 , the optimal marginal cost reduction, $x{ }^{*} C$ under symmetric information, is below the "first-best" level symmetric information, $x_{s o}$ and so the signaling brings it closer to its "first-best" level. Unlike in the no signaling case, the increase in social welfare level above its symmetric information level with government intervention may occur only under Cournot competition. When the true conduct is Bertrand and a separating equilibrium exists, the social welfare levels under symmetric and asymmetric information are equal. ${ }^{22}$

\section{CONCLUDING REMARKS}

\footnotetext{
${ }^{22}$ When condition (26) holds but a signaling equilibrium does not exist either because there is no level of R\&D such that the incentive compatibility constraints (27) and (27') are simultaneously verified, or because the government does not have a priori beliefs that can sustain a signaling equilibrium, then a pooling equilibrium might arise in the market. In this case it is straightforward to show that the level of tariff protection should be higher than $t^{{ }^{*} B}$ and a Bertrand firm invests in R\&D more than $x^{{ }^{*} B}$, its R\&D level under full information. Then the inferences from such equilibrium are similar with the one described in section 7.1 (no signaling case). However, none of the pooling equilibrium survives the Cho and Kreps (1987) intuitive criterion.
} 
The focus of our policy analysis was the simple and, in reality, most frequently used "tariffs cum foreign competition" set-up designed to protect a domestic industry and enhance its competitive position. This policy framework can appear in several variants due to reasons such as the mode of the oligopoly conduct; the (in)ability of the domestic government to commit to its policy; and information asymmetry.

In the first part of the paper we assumed a perfect, symmetric information set-up and explored the role of oligopoly conduct and the ability of the domestic government to commit to the level of its policy instrument. We considered three policy options: the government commitment regime, the government non-commitment regime, and free trade. We found that, regardless of the market conduct and the ability of the domestic government to commit in advance to the level of its policy, the optimal tariff protection enhances not only the domestic social welfare but also the innovative effort of the domestic firm. However, free trade, as a policy option per se, also has its virtues, since the information requirement for its implementation is virtually zero. Thus, we introduced other policy criteria beyond generated social welfare (i.e., the information requirement, time consistency, and the risk of agency and manipulative behavior) in order to evaluate the policy options under consideration. We found that the most robust policy choice is the government "non-commitment" regime that has a low information requirement, and in which the optimal tariff is time consistent and the risk of manipulation by the domestic firm is absent. In addition, the social welfare loss vis-à-vis the government commitment regime is negligible.

An independent and interesting result of the first part of the analysis is the comparison between the corresponding equilibrium values of the innovative efforts and tariffs. Thus, in the government "non-commitment" regime, the optimal Cournot tariff is higher than the analogous Bertrand tariff, and consequently, the innovative effort of the Cournot type of firm exceeds that of the Bertrand type. (The same relation between R\&D efforts and tariffs seems to hold in a commitment regime, but we managed to prove this only in the case of the specific functional form of the innovative cost function.)

In the second part of the paper, we discuss two kinds of information asymmetry and briefly explored how the most desirable policy under perfect information - a non-commitment regime - fared, in the presence of the government's uncertainty about the market conduct. The first type of uncertainty is deemed the stronger since the domestic government is presumed not to be able to learn anything about market conduct and has to rely only on its 
prior beliefs in setting the policy. The second type of uncertainty is the standard one in which the government is able to update its beliefs after observing the R\&D effort of the domestic firm that can signal its type.

The asymmetric information set-up is less information intensive but in general worsens social welfare compared to the analogous symmetric information set-up. Nevertheless, we identified situations when the expected social welfare can be higher than the corresponding social welfare levels under the symmetric information assumption. In the strong kind of information asymmetry, this happens when Bertrand is the true type conduct and the government probability associated with this true conduct is "not too low". In the case of the second type of information asymmetry, this occurs when a separating equilibrium exists under Cournot competition and products are "differentiated enough". In such a situation an increase of the innovative effort due to signaling either approaches the first best innovative effort from below or does not exceed it "too much". 


\section{ApPendix 1: ProOf of PROPOSITION 1}

We have already showed that $t^{* B}<t^{* C}$ and that, from the social point of view, both Cournot and Bertrand types of firm under-invest in R\&D. Therefore, it remains only to show that $x^{* B}<x^{*}$. To prove the relation between R\&D levels in different types of market conduct, we first eliminate $V_{d}$ in equation (16) by using the fact that $V_{d} \beta_{f}-V_{f} \beta_{d}=0$. Then we differentiate the resulted equation with respect to $V_{f}$ and we get

$$
\begin{gathered}
\frac{d x}{d V_{f}}\left(k i^{\prime \prime}\left(x^{*}\right)-\frac{2 \beta_{d} \beta_{f} V_{f}\left(V_{f}+\beta_{f}\right)^{2}}{\left[\beta_{d}\left(V_{f}+\beta_{f}\right)^{2}-\beta_{f} \gamma^{2}\right]^{2}}\right)=\frac{2 \beta_{d} \beta_{f} V_{f}\left[\beta_{d}\left(V_{f}+\beta_{f}\right)^{2}-\left(2 V_{f}+\beta_{f}\right) \gamma^{2}\right]}{\left[\beta_{d}\left(V_{f}+\beta_{f}\right)^{2}-\beta_{f} \gamma^{2}\right]^{2}} q^{d}+ \\
+\frac{2 \beta_{d} \beta_{f} V_{f}\left(V_{f}+\beta_{f}\right)}{\left[\beta_{d}\left(V_{f}+\beta_{f}\right)^{2}-\beta_{f} \gamma^{2}\right]^{2}}\left(\left(\alpha_{d}-c+x^{*}\right)+\gamma \frac{\alpha_{f} \beta_{f}}{\left(2 V_{f}+\beta_{f}\right)^{2}}\right) .
\end{gathered}
$$

Due to assumption (A3), the left hand side parenthesis is bigger than zero. In addition, for both Bertrand and Cournot conjectures $\beta_{d}\left(V_{f}+\beta_{f}\right)^{2}-\left(2 V_{f}+\beta_{f}\right) \gamma^{2}>0$. Then, the right hand side is positive so $d x / d V_{f}$ is positive, and since $V_{f}{ }^{C}>V_{f}^{B}$, we find that $x^{{ }^{B}}<x^{*}$.

\section{APPENDIX 2: ProOF OF PROPOSITION 2}

The social welfare function (6) is separable in $t$ and $x$. Its first derivative with respect to $t$ is given by (10) and is a linear function in $t$, positive in $t=0$. Consequently, as long as the tariff increases towards $t^{*}=t_{s o}$, the domestic social welfare increases. With respect to $x$, the first derivative is given by (13) or equivalently, by $q^{d}\left(x, t_{s o}\right) \frac{2 V_{d}+\beta_{d}}{V_{d}+\beta_{d}}-k i^{\prime}(x) \geq 0$. Due to assumption (A2) this derivative is strictly positive in $x=0$. Moreover, the solution of this derivative equal to zero is the socially optimum investment level $x_{s o}$. Consequently, as long as the level of investment increases towards $x_{s o}$, domestic social welfare increases. Since 0 (the free trade level for tariff) $<t^{*}$ and since for product substitutes, $x_{f t} \leq x^{*} \leq x_{s o}$ (with equality if we have corner solutions for the R\&D level), free trade brings lower social welfare than the optimal tariff does.

When we take the total derivative of the domestic profit given by equation (5) with respect to $t$ and use in it the envelope theorem (for the R\&D choice), we obtain that 
$\frac{d \pi^{d}}{d t}=2 V_{d} q^{d} \frac{\partial q^{d}}{\partial t}$, where $q^{d}$ is given by (4). Since $\partial q^{d} / \partial t$ is positive, the domestic profit increases as the tariff increases.

\section{ApPENDIX 3: ProOf of PROPOSITION 3}

We use the fact that the social welfare function $W(x, t)$ is separable in $t$ and $x$ and we denote by $\partial W / \partial t=\partial W / \partial t(x, t)$ and by $\partial W / \partial x=\partial W / \partial x(x, t)$. We recall from the discussion in the proof for Proposition 2 that $\partial W / \partial t$ is positive for $t<t^{*}$ and negative otherwise, and that $\partial W / \partial x$ is positive for $x<x_{s o}$. As we saw from equation (19), it follows that $\partial X / \partial t \geq 0$ (with equality only for corner solutions in R\&D).

When the optimal tariff is chosen before the domestic firm decides on its innovative effort, the domestic government solves

$$
\frac{d W}{d t}=\frac{\partial W}{\partial t}+\frac{\partial W}{\partial x} \frac{\partial X}{\partial t}=0
$$

This will yield a different solution than when the government cannot commit in advance to its policy. In that case it only solves $\partial W / \partial t=0$ and thus chooses the tariff $t^{*}$. However at $t^{*}$ tariff protection the domestic firm chooses a level of R\&D investment equal to $x^{*}$, a level which is below the corresponding socially optimal value. Thus at $t^{*} d W / d t$ is positive. If the government chooses a $t<t^{*}$ then $\partial W / \partial t>0$ and moreover $\partial W / \partial x>0$ (since such a tariff will induce a level of R\&D lower than or equal to $x^{*}$ ). Thus at $t<t^{*} d W / d t$ remains positive. Consequently the optimal tariff should be above or equal to $t^{*}$ with equality holding for $x^{*}=c$. If $x^{*}$ is below $c$, then, if the tariff is high enough to induce investment levels above or equal to $x_{s o}, d W / d t$ becomes negative $(\partial W / \partial t<0, \partial W / \partial x \leq 0)$. To conclude, the optimal tariff $T^{*}$ should be higher than the optimal one without government commitment, but not so high as to induce the socially optimal level of innovation. Thus $X^{*}$ will be above $x^{*}$ but below the socially optimal value of innovation, $x_{s o}$.

\section{APPENDIX 4: THE CASE WHEN $f(x)=x^{2} / 2$}

When we replace in (19) the quadratic form of the investment function and the formula (4) for $q^{d}(X, t)$ we find that, given the level of tariff $t$, in the second stage the 
domestic firm chooses a level of R\&D of

$$
X(t)=\frac{2 V_{d}\left(V_{f}+\beta_{f}\right)}{k\left[\left(V_{d}+\beta_{d}\right)\left(V_{f}+\beta_{f}\right)-\gamma^{2}\right]^{2}-2 V_{d}\left(V_{f}+\beta_{f}\right)^{2}}\left[\left(V_{f}+\beta_{f}\right)\left(\alpha_{d}-c\right)-\gamma\left(\alpha_{f}-t\right)\right] .
$$

To derive the optimal tariff level we replace this formula in (23) together with the formulas for Cournot and Bertrand conjectures, and we obtain

$$
T^{* C}=\frac{\alpha_{f}}{3}+\gamma \frac{4 k \beta_{f}\left(4 \beta_{d} \beta_{f}-3 \gamma^{2}\right)\left[3 \beta_{f}\left(\alpha_{d}-c\right)-\alpha_{f} \gamma\right]}{3\left[3 k^{2}\left(4 \beta_{d} \beta_{f}-\gamma^{2}\right)^{3}-64 k \beta_{d} \beta_{f}^{2}\left(3 \beta_{d} \beta_{f}-\gamma^{2}\right)+48 \beta_{d} \beta_{f}^{3}\right]}
$$

for quantity competition and

$$
T^{{ }^{* B} B}=\frac{\alpha_{f}}{3+\frac{\gamma^{2}}{\beta_{d} \beta_{f}-\gamma^{2}}}+\gamma \frac{2 k \beta_{d} \beta_{f}{ }^{3}\left(4 \beta_{d} \beta_{f}-3 \gamma^{2}\right)\left(2 \beta_{d} \beta_{f}-\gamma^{2}\right)\left[\left(3 \beta_{d} \beta_{f}-2 \gamma^{2}\right)\left(\alpha_{d}-c\right)-\alpha_{f} \beta_{d} \gamma\right]}{\left(3 \beta_{d} \beta_{f}-2 \gamma^{2}\right) D_{B}}
$$

where

$$
\begin{aligned}
D_{B}= & k^{2}\left(4 \beta_{d} \beta_{f}-\gamma^{2}\right)^{3}\left(3 \beta_{d} \beta_{f}-2 \gamma^{2}\right)\left(\beta_{d} \beta_{f}-\gamma^{2}\right)-8 k \beta_{f}\left(2 \beta_{d} \beta_{f}-\gamma^{2}\right)^{2}\left(6 \beta_{d}{ }^{2} \beta_{f}{ }^{2}-6 \beta_{d} \beta_{f} \gamma^{2}+\gamma^{4}\right) \\
& +4 \beta_{f}{ }^{2}\left(2 \beta_{d} \beta_{f}-\gamma^{2}\right)^{2}\left(3 \beta_{d} \beta_{f}-2 \gamma^{2}\right)
\end{aligned}
$$

for price competition.

We did not make the comparison between $T^{* C}$ and $T^{* B}$ so one could have conjectured that $T^{*}{ }^{*}>T^{* B}$ as was the case in the non-commitment regime (that is, $t^{{ }^{*} C}>t^{* B}$ ). However, this is not completely clear since we should recall that in the commitment case, the government influences the level of domestic firm's R\&D level and unit cost reduction. To the extent that these levels are more suboptimal in the Bertrand case than in the Cournot case we may expect that the difference, $T^{* B}-t^{* B}$ is bigger than $T^{* C}-t^{*} C$. In other words, the optimal commitment tariff may increase more in the case of Bertrand competition above its non-commitment counterpart than is the case in Cournot competition. So it is a priori unclear whether this impact can be strong enough to drive the optimal Bertrand tariff above the Cournot one in the commitment regime. The expressions for $T^{*} C$ and $T^{* B}$ are rather complex, so we were unable to find the exact relations between $T^{*} C$ and $T^{* B}$. However, in our example with quadratic investment function, when we considered symmetric demands with $\alpha_{d}=\alpha_{f}=1$ and $\beta_{d}=\beta_{f}=$ 1, we could show by simulations that $T^{* B}$ is never bigger than $T^{*} C$. 


\section{APPENDIX 5: PROOF OF PROPOSITION 4}

A domestic firm that correctly anticipates a tariff protection level of $t^{u}$ chooses a level of R\&D given by (16) with the amendment that $t^{*}$ is replaced by $t^{u}$. Since $t^{u}$ does not depend on the level of innovation, the corresponding level of $R \& D$ equals the $R \& D$ choice of a firm facing a committed government that announces a $t^{u}$ level of tariff protection (see formula 19). Thus, for any given level of tariff $t$, social welfare in the case of non-commitment regime equals the social welfare under commitment, provided that in the former case the domestic firm correctly anticipates the level $t$ of the tariff.

We know from Proposition 3 that as long as the tariff increases towards $T{ }^{*}$ social welfare increases as well. In Bertrand competition, $t^{u}$ is always higher than $t^{* B}$. In addition, for some values of $\eta$ that are close enough to 1 , the continuity of $t^{u}$ in $\eta$ ensures that $t^{u B}$ is smaller than $T^{* B}$. Thus, for such values of $\eta$, social welfare under the protection level, $t^{u}$, is always higher than social welfare under $t^{* B}$ (On the other hand, when products are almost homogenous and $\eta$ is close to 0 so that the tariff level $t^{u}$ approaches $t^{*} C$, such a high protection level might drive the domestic social welfare to levels even lower than the free trade level.).

The social welfare function (described by formula (6)) increases in $t$ for $t \leq t^{*}$ and increases in $x$ for $x \leq x_{s o}$. The tariff $t^{u}$ is above 0 , which is the free trade "tariff", but below $t^{*}$. Also, the level of R\&D chosen by the domestic firm under tariff protection $x^{*}$ is above the free trade level (but below or equal to $x_{s o}$ ). Thus, the optimal tariff under uncertainty $t^{u}$ enhances the domestic social welfare with respect to the free trade outcome, but reduces social welfare to below the symmetric information level.

APPENDIX 6: SOCIAL WELFARE COMPARISON BETWEEN THE FT AND GNCR AND GNCR AND GCR REGIMES

The investment function is assumed to be quadratic and is given by $i(x)=\frac{1}{2} k x^{2}$. We also set $\alpha_{d}=\alpha_{f}=\beta_{d}=\beta_{f}=1$, and $k=2$. In order to avoid underestimating the overall gains from introducing a tariff, we rule out the possibility of having corner solutions for the innovation levels. Therefore, apart from satisfying the (A1) - (A3) assumptions, parameters $c$ and $\gamma$ should also be such that the reduction in marginal costs, $\mathrm{x}$, are smaller than $c$. 


\section{A6. 1. Free Trade versus the Non-Commitment Policy Regime}

The optimal levels of increase in efficiency under a non-committed government, $x^{* B}$ and $x^{*}$, are implicitly given by formula (16). Having a quadratic investment function, we can explicitly solve equation (16). When we substitute the corresponding levels of $V_{d}$ and $V_{f}$ in this equation and solve for $x$ we find that the level of increase in efficiency in the case of Bertrand competition $\left(V_{d}=V_{f}=1-\gamma^{2}\right), x^{* B}$, equals

$$
x^{* B}=\frac{2\left(2-\gamma^{2}\right)^{2}\left[(1-c)\left(\left(3-2 \gamma^{2}\right)-2 \gamma^{2}\right]\right.}{\left(3-2 \gamma^{2}\right)\left[k\left(1-\gamma^{2}\right)\left(4-\gamma^{2}\right)^{2}-2\left(2-\gamma^{2}\right)^{2}\right]}
$$

while the level of increase in efficiency for Cournot competition $\left(V_{d}=V_{f}=1\right), x^{*}$, is given by

$$
x^{* C}=\frac{8[3(1-c)-\gamma]}{3 k\left(4-\gamma^{2}\right)^{2}-24} \text {. }
$$

The fact that these levels of $x$ should be smaller than $c$ adds to the (A1) - (A3) assumptions lower bound restrictions on $c$. In Bertrand competition, the marginal cost, $c$, should be at least as high as

$$
c>\frac{(3+2 \gamma)\left(2-\gamma^{2}\right)^{2}}{(1+\gamma)\left(3-2 \gamma^{2}\right)\left(4-\gamma^{2}\right)^{2}}
$$

while in Cournot competition it should be no lower than

$$
c>\frac{4(3-\gamma)}{3\left(4-\gamma^{2}\right)^{2}}
$$

in order to have interior solutions for R\&D investment.

The percentage gains in social welfare from having an optimal tariff protection set by a non-committed government with respect to the free trade outcome is given in Table 2 and Table 3. In Table 2, we consider the case when firms choose prices, and we assume that (A1) - (A4) hold. To generate Table 3, we assume that firms set quantities and conditions (A1) (A3), (A5) hold. 
Table 2. Percentage differences between domestic social welfare under free trade and noncommitment when firms compete in prices ${ }^{*}$

\begin{tabular}{|c|c|c|c|c|c|c|c|c|c|c|c|c|c|c|}
\hline$\gamma / \mathrm{c}$ & 0.25 & 0.3 & 0.35 & 0.4 & 0.45 & 0.5 & 0.55 & 0.6 & 0.65 & 0.7 & 0.75 & 0.8 & 0.85 & 0.9 \\
\hline 0.05 & 9.99 & 11.00 & 12.14 & 13.43 & 14.89 & 16.52 & 18.34 & 20.33 & 22.47 & 24.71 & 26.96 & 29.09 & 30.94 & 32.34 \\
\hline 0.15 & 10.85 & 11.94 & 13.17 & 14.56 & 16.12 & 17.85 & 19.74 & 21.80 & 23.95 & 26.14 & 28.23 & 30.09 & 31.55 & \\
\hline 0.25 & 11.63 & 12.79 & 14.09 & 15.56 & 17.18 & 18.97 & 20.89 & 22.93 & 25.00 & 27.01 & 28.81 & 30.24 & 31.15 & \\
\hline 0.35 & 12.34 & 13.56 & 14.92 & 16.42 & 18.08 & 19.86 & 21.74 & 23.66 & 25.51 & 27.18 & 28.51 & 29.36 & & \\
\hline 0.45 & 13.02 & 14.27 & 15.65 & 17.16 & 18.78 & 20.48 & 22.20 & 23.84 & 25.30 & 26.43 & 27.10 & & & \\
\hline 0.55 & 13.70 & 14.96 & 16.31 & 17.75 & 19.23 & 20.70 & 22.06 & 23.21 & 24.01 & 24.34 & & & & \\
\hline 0.65 & 14.49 & 15.68 & 16.91 & 18.13 & 19.26 & 20.21 & 20.87 & 21.12 & & & & & & \\
\hline 0.75 & 15.70 & 16.63 & 17.43 & 17.99 & 18.18 & 17.91 & 17.11 & & & & & & & \\
\hline 0.85 & 19.22 & 18.50 & 16.79 & 14.08 & & & & & & & & & & \\
\hline
\end{tabular}

Table 3. Percentage differences between domestic social welfare under free trade and noncommitment when firms compete in quantities ${ }^{*}$

\begin{tabular}{|c|c|c|c|c|c|c|c|c|c|c|c|c|c|c|}
\hline$\underline{\gamma / c}$ & 0.25 & 0.3 & 0.35 & 0.4 & 0.45 & 0.5 & 0.55 & 0.6 & 0.65 & 0.7 & 0.75 & 0.8 & 0.85 & 0.9 \\
\hline 0.05 & 10.01 & 11.02 & 12.17 & 13.47 & 14.93 & 16.56 & 18.38 & 20.38 & 22.53 & 24.78 & 27.04 & 29.18 & 31.04 & 32.45 \\
\hline 0.15 & 11.04 & 12.16 & 13.43 & 14.85 & 16.45 & 18.23 & 20.19 & 22.31 & 24.54 & 26.81 & 29.00 & 30.94 & 32.47 & 33.41 \\
\hline 0.25 & 12.18 & 13.42 & 14.82 & 16.39 & 18.15 & 20.09 & 22.20 & 24.44 & 26.75 & 29.00 & 31.06 & 32.73 & 33.84 & \\
\hline 0.35 & 13.45 & 14.83 & 16.39 & 18.13 & 20.07 & 22.19 & 24.47 & 26.84 & 29.19 & 31.39 & 33.24 & 34.54 & & \\
\hline 0.45 & 14.89 & 16.44 & 18.19 & 20.14 & 22.29 & 24.62 & 27.08 & 29.58 & 31.96 & 34.03 & 35.57 & 36.37 & & \\
\hline 0.55 & 16.54 & 18.30 & 20.28 & 22.49 & 24.90 & 27.49 & 30.16 & 32.78 & 35.13 & 36.98 & 38.07 & & & \\
\hline 0.65 & 18.47 & 20.50 & 22.78 & 25.31 & 28.07 & 30.97 & 33.89 & 36.62 & 38.87 & 40.35 & & & & \\
\hline 0.75 & & 23.14 & 25.83 & 28.80 & 32.02 & 35.34 & 38.57 & 41.39 & 43.42 & 44.31 & & & & \\
\hline 0.85 & & 26.41 & 29.68 & 33.30 & 37.18 & 41.11 & 44.76 & 47.65 & 49.28 & & & & & \\
\hline 0.95 & & 30.57 & 34.74 & 39.40 & 44.39 & 49.35 & 53.70 & 56.69 & & & & & & \\
\hline
\end{tabular}

Apart from the clear dominance of a GNC regime in terms of social welfare, it is interesting to note in the case of Cournot competition, the performance of a tariff protection regime with respect to free trade increases with an increase in the initial domestic firm's marginal cost level, $c$, and with a decrease in the level of product differentiation. Similar relations hold in the case of Bertrand competition when products are not very similar $(\gamma \leq$ 0.65). Finally, at least for medium and low levels of $\gamma(\gamma \leq 0.65)$, and values of $c$ that satisfy 
both (A4) and (A5) restrictions, we can see that the percentage gains from tariff protection relative to free trade are quite similar in both types of market conduct.

\section{A6. 2. Non-Commitment versus Commitment Regime}

As in the above section, we take into consideration only interior solutions for the innovation levels. Thus, as before, besides satisfying the (A1) - (A3) assumptions, parameters $c$ and $\gamma$ should be such that $X^{* B}$ and $X^{* C}$ are smaller than $c$.

To compute the optimal levels of increase in efficiency, we first replace in (19) the quadratic form of the investment function and the formula (4) for $q^{d}(X, t)$. We find that, given the level of tariff $t$, in the second stage the domestic firm chooses a level of R\&D of

$$
X(t)=\frac{V_{d}\left(V_{f}+1\right)}{\left[\left(V_{d}+1\right)\left(V_{f}+1\right)-\gamma^{2}\right]^{2}-V_{d}\left(V_{f}+1\right)^{2}}\left[\left(V_{f}+1\right)(1-c)-\gamma(1-t)\right] .
$$

Next, we derive the optimal tariff levels by replacing the above formula in (23) together with the formulas for Cournot and Bertrand conjectures. The optimal tariff protection for quantity competition is

$$
T^{{ }^{*} C}=\frac{1}{3}+\gamma \frac{4 k\left(4-3 \gamma^{2}\right)[3(1-c)-\gamma]}{3\left[3 k^{2}\left(4-\gamma^{2}\right)^{3}-64 k\left(3-\gamma^{2}\right)+48\right]}
$$

and for price competition

$$
T^{{ }^{*} B}=\frac{1-\gamma^{2}}{3-2 \gamma^{2}}+\gamma \frac{2 k\left(4-3 \gamma^{2}\right)\left(2-\gamma^{2}\right)\left[\left(3-2 \gamma^{2}\right)(1-c)-\gamma\right]}{\left(3-2 \gamma^{2}\right) D_{B}}
$$

where

$D_{B}=k^{2}\left(4-\gamma^{2}\right)^{3}\left(3-2 \gamma^{2}\right)\left(1-\gamma^{2}\right)-8 k\left(2-\gamma^{2}\right)^{2}\left(6-6 \gamma^{2}+\gamma^{4}\right)+4\left(2-\gamma^{2}\right)^{2}\left(3-2 \gamma^{2}\right)$.

Finally, we obtain the optimal levels of increase in efficiency, $X^{* B}$ and $X^{* C}$, by replacing in the formula for $X(t)$ the corresponding levels of $V_{d}$ and $V_{f}$ and of tariff protection. The level of $X^{* B}$ is given by

$$
X^{* B}=\frac{2\left(2-\gamma^{2}\right)^{2}\left[k\left(4-\gamma^{2}\right)-2\right]\left[(1-c)\left(\left(3-2 \gamma^{2}\right)-2 \gamma^{2}\right]\right.}{k^{2}\left(4-\gamma^{2}\right)^{3}\left(3-2 \gamma^{2}\right)\left(1-\gamma^{2}\right)-8 k\left(2-\gamma^{2}\right)^{2}\left(6-6 \gamma^{2}+\gamma^{4}\right)+4\left(2-\gamma^{2}\right)^{2}\left(3-2 \gamma^{2}\right)}
$$

and the level of $X^{*} C$ is given by

$$
X^{*_{C} C}=\frac{8\left[k\left(4-\gamma^{2}\right)-2\right][3(1-c)-\gamma]}{3 k^{2}\left(4-\gamma^{2}\right)^{3}-64 k\left(3-\gamma^{2}\right)+48} .
$$


These levels of increase in efficiency are below $c$ if

$$
c>\frac{\left(3-\gamma-2 \gamma^{2}\right)\left(3-\gamma^{2}\right)\left(2-\gamma^{2}\right)^{2}}{144-364 \gamma^{2}+332 \gamma^{4}-138 \gamma^{6}+27 \gamma^{8}-2 \gamma^{10}}
$$

in Bertrand competition, and if

$$
c>\frac{4(3-\gamma)\left(3-\gamma^{2}\right)}{144-124 \gamma^{2}+36 \gamma^{4}-3 \gamma^{6}}
$$

in Cournot competition.

The percentage gains in social welfare from having the optimal tariff protection set by a committed government rather than a non-committed one are given in Table 4 for price competition and in Table 5 for quantity competition. In the first case, we assume that (A1) (A3) and (A6) hold while in the latter case, we assume that conditions (A1) - (A3), and (A7) are satisfied.

Table 4. Percentage differences between domestic social welfare under non-commitment and

\begin{tabular}{|c|c|c|c|c|c|c|c|c|c|c|c|c|c|c|}
\hline$\gamma / \mathrm{c}$ & 0.25 & 0.3 & 0.35 & 0.4 & 0.45 & 0.5 & 0.55 & 0.6 & 0.65 & 0.7 & 0.75 & 0.8 & 0.85 & 0.9 \\
\hline 0.05 & 0.00060 & 0.00057 & 0.00053 & 0.00050 & 0.00045 & 0.00041 & 0.00036 & 0.00031 & 0.00025 & 0.00020 & 0.00014 & 0.00009 & 0.00005 & 0.00002 \\
\hline 0.15 & 0.00550 & 0.00519 & 0.00484 & 0.00445 & 0.00403 & 0.00357 & 0.00308 & 0.00257 & 0.00204 & 0.00153 & 0.00104 & 0.00061 & 0.00028 & \\
\hline 0.25 & 0.01645 & 0.01540 & 0.01423 & 0.01295 & 0.01156 & 0.01006 & 0.00848 & 0.00684 & 0.00521 & 0.00366 & 0.00227 & 0.00114 & 0.00036 & \\
\hline 0.35 & 0.03674 & 0.03408 & 0.03114 & 0.02793 & 0.02446 & 0.02077 & 0.01694 & 0.01308 & 0.00936 & 0.00598 & 0.00317 & 0.00115 & & \\
\hline 0.45 & 0.07389 & 0.06767 & 0.06086 & 0.05347 & 0.04559 & 0.03737 & 0.02904 & 0.02095 & 0.01353 & 0.00730 & 0.00277 & & & \\
\hline 0.55 & 0.14562 & 0.13092 & 0.11493 & 0.09782 & 0.07993 & 0.06179 & 0.04419 & 0.02812 & 0.01475 & 0.00521 & & & & \\
\hline 0.65 & 0.30081 & 0.26206 & 0.22055 & 0.17721 & 0.13356 & 0.09178 & 0.05461 & 0.02515 & & & & & & \\
\hline 0.75 & & 0.58953 & 0.45113 & 0.31499 & 0.19068 & 0.08962 & 0.02321 & & & & & & & \\
\hline 0.85 & & 1.92371 & 0.96067 & 0.27264 & & & & & & & & & & \\
\hline
\end{tabular}
commitment when firms compete in prices* 
Table 5. Percentage differences between domestic social welfare under non-commitment and commitment when firms compete in quantities ${ }^{*}$

\begin{tabular}{|c|c|c|c|c|c|c|c|c|c|c|c|c|c|c|}
\hline$\overline{\gamma / \mathrm{c}}$ & 0.25 & 0.3 & 0.35 & 0.4 & 0.45 & 0.5 & 0.55 & 0.6 & 0.65 & 0.7 & 0.75 & 0.8 & 0.85 & 0.9 \\
\hline$\overline{0.05}$ & 0.00060 & 0.00056 & 0.00053 & 0.00049 & 0.00045 & 0.00041 & 0.00036 & 0.00030 & 0.00025 & 0.00020 & 0.00014 & 0.00009 & 0.00005 & 0.00002 \\
\hline 0.15 & 0.00524 & 0.00494 & 0.00461 & 0.00425 & 0.00385 & 0.00341 & 0.00295 & 0.00246 & 0.00196 & 0.00146 & 0.00100 & 0.00059 & 0.00027 & 0.00007 \\
\hline 0.25 & 0.01435 & 0.01345 & 0.01245 & 0.01136 & 0.01016 & 0.00887 & 0.00750 & 0.00608 & 0.00466 & 0.00329 & 0.00207 & 0.00106 & 0.00036 & \\
\hline 0.35 & 0.02794 & 0.02601 & 0.02388 & 0.02154 & 0.01899 & 0.01627 & 0.01342 & 0.01051 & 0.00768 & 0.00505 & 0.00281 & 0.00114 & & \\
\hline 0.45 & 0.04614 & 0.04264 & 0.03877 & 0.03454 & 0.02997 & 0.02511 & 0.02010 & 0.01510 & 0.01036 & 0.00617 & 0.00286 & 0.00074 & & \\
\hline 0.55 & 0.06904 & 0.06329 & 0.05694 & 0.05001 & 0.04256 & 0.03475 & 0.02681 & 0.01909 & 0.01205 & 0.00621 & 0.00210 & & & \\
\hline 0.65 & 0.09622 & 0.08742 & 0.07771 & 0.06715 & 0.05589 & 0.04421 & 0.03257 & 0.02161 & 0.01212 & 0.00494 & & & & \\
\hline 0.75 & & 0.11312 & 0.09920 & 0.08411 & 0.06814 & 0.05182 & 0.03596 & 0.02165 & 0.01013 & 0.00262 & & & & \\
\hline 0.85 & & 0.13482 & 0.11642 & 0.09653 & 0.07566 & 0.05472 & 0.03504 & 0.01828 & 0.00623 & & & & & \\
\hline 0.95 & & 0.13825 & 0.11730 & 0.09469 & 0.07122 & 0.04821 & 0.02751 & 0.01136 & & & & & & \\
\hline
\end{tabular}




\section{REFERENCES}

D'Aspremont, C. and A. Jacquemin (1988): "Cooperative and Noncooperative R\&D in Duopoly with Spillovers," American Economic Review 78(5): 1133-1137.

Bagwell, K. and R.W. Staiger (1994): "The Sensitivity of Strategic and Corrective R\&D Policy in Oligopolistic Industries," Journal of International Economics 36: 133-150.

Bester, H. and E. Petrakis (1993): "The Incentives for Cost Reduction in a Differentiated Industry," International Journal of Industrial Organization 11: 519-534.

Bhattacharjea, A. (2002): "Infant Industry Protection, Revisited: Entry-Deterrence and Entry Promotion when a Foreign Monopolist has Unknown Costs," International Economic Journal, 16(3): 115-133.

Bhattacharjea, A. (1995): "Strategic Tariffs and Endogenous Market Structure: Trade and Industrial Policies under Imperfect Competition," Journal of Development Economics 47: 287-312.

Bouët, A. (2001): "Research and Development, voluntary export restriction and tariffs," European Economic Review 45 (2): 323-336.

Brander, J.A. and B.J. Spencer (1985): "Export Subsidies and Market Share Rivalry," Journal of International Economics 18: 83-100.

Carmichael, C (1987): "The Control of Export Credit Subsidies and Its Welfare Consequences," Journal of International Economics 23:1-9.

Cheng, L.K. (1988): "Assessing Domestic Industries under International Oligopoly: The Relevance of the Nature of Competition to Optimal Policies," American Economic Review 78: 746-758.

Cho, I-K. and D. Kreps. (1987): "Signaling games and stable equilibria", Quarterly Journal of Economics, 102: 179-221.

Das, S.P., (2002): "Foreign direct investment and the relative wage in a developing economy," Journal of Development Economics 67: 55-77.

Dixit, A. (1988): "Anti-dumping and Countervailing Duties under Oligopoly," European Economic Review 32: 55-68.

Eaton, J. and G. Grossman (1986): "Optimal Trade and Industrial Policy under Oligopoly," Quarterly Journal of Economics 101(2): 383-406.

Fudenberg, D. and J. Tirole (1984): "The fat-cat effect, the puppy-dog ploy, and the lean and hungry look," American Economic Review, Papers and Proceedings 74: 361-366.

Goldberg, P.K. (1995): "Strategic export promotion in the absence of government precommitment," International Economic Review 36: 407-426.

Grossman, G.M. and G. Maggi (1998): "Free Trade vs. Strategic Trade: A Peak into Pandora's Box," in R. Sato, R.V. Ramachandran and K. Mino (eds.), Global Competition and Integration, Kluwer Academic Publishers: Dordrecht, pp. 9-32.

Helpman, E. and P.R. Krugman (1989): Trade Policy and Market Structure, Cambridge, Mass. and London: MIT Press, pages xii, 191.

Ionaşcu, D. and K. Žigić (2001): "Free Trade versus Strategic Trade as a Choice between Two 
'Second-best' Policies: A Symmetric versus Asymmetric Information Analysis," CEPR Discussion Paper, No. 2928.

Karp, L. S. and J. M. Perloff (1995): "The Failure of Strategic Industrial Policies due to Manipulation by Firms," International Review of Economics and Finance 4(1): 1-16.

Klemperer and Meyer (1986): "Price Competition vs. Quantity Competition: The Role of Uncertainty," RAND Journal of Economics 17(4): 618-638.

Krugman, P. (1989): "New Trade Theory and the Less Developed Countries," in G. Calvo, etal. Debt, stabilization and development: Essays in memory of Carlos Diaz-Alejandro, Blackwell, Oxford: 347-65.

Leahy, D. and J.P. Neary (1999): "Learning by doing, precommitment and infant industry promotion," Review of Economic Studies, 66(2): 447-474.

Maggi, G. (1996): "Strategic Trade Policies with Endogenous Mode of Competition," The American Economic Review 86 (1): 237-258.

Maggi, G.(1999): "Strategic trade policy under incomplete information," International Economic Review 40: 571-594.

Martin, S. (1993): Advanced Industrial Economics, Oxford Mass.: Blackwell.

Miravete, J. E. (2001) Time-Consistent Protection with Learning by Doing, CEPR Discussion Paper, No. 2937.

Motta, Massimo (1992): "Multinational Firms and the Tariff-Jumping Argument: A Game Theoretic Analysis with Some Unconventional Conclusions," European Economic Review 36: 1557-1571.

Neary, J.P. and D. Leahy (2000): "Strategic Trade and Industrial Policy towards Dynamic Oligopolies," Economic Journal 110: 484-508.

Neary, J.P. and P. O'Sullivan (1999): "Beat 'Em or Join 'Em? Export Subsidies versus International Research Joint Ventures in Oligopolistic Markets," Scandinavian Journal of Economics 101: 577-596.

Qiu, L. (1994): “Optimal Strategic Trade Policy under Asymmetric Information,“ Journal of International Economics 36(3-4): 333-354.

Qiu, L.D. and Lai, L.-C. E. (2001): "Protection of Trade for Innovation: The Roles of Northern and Southern Tariffs," mimeo.

Reitzes, J.D. (1991): "The impact of quotas and tariffs on Strategic R\&D behavior," International Economic Review 32(4): 985-1007.

Rodríguez, F, and Rodrik, D. (2001) "Trade Policy and Economic Growth: A Skeptic's Guide to the Cross-National Evidence": in B. Bernanke and K. S. Rogoff, eds. Macroeconomics Annual 2000, NBER, Cambridge, MA.

Rodrik, D. (2001) "The Global Governance of Trade; As if Development Really Mattered", UNDP, New York.

Singh, N. and X. Vives (1984): "Price and Quantity Competition in a Differentiated Duopoly," Rand Journal of Economics 15: 546-554. 
Tirole, J. (1991): The Theory of Industrial Organization. Cambridge, MA and London: 'The MIT Press.

Wright, D. J. (1995): “Incentives, Protection, and Time Consistency", The Canadian Journal of Economics 28 (4a): 929-938.

Žigić, K.(2000): "Strategic Trade Policy, Intellectual Property Rights Protection, and NorthSouth Trade," Journal of Development Economics 61(1): 27-60,

Žigić, K. (2003): 'Does 'Non-Committed' Government Always Generate Lower Social Welfare Than Its 'Committed' Counterpart?” CEPR Discussion Paper, No. 394 
Individual researchers, as well as the on-line and printed version of the CERGE-EI Working Papers Series (including their dissemination) were supported from the following institutional grants:

- Economic Impact of European Integration on the Czech Republic [Ekonomické dopady evropské integrace na ČR], No. MSM0021620846, (2005-2011);

Specific research support and/or other grants the researchers/publications benefited from are acknowledged at the beginning of the Paper.

(c) Delia lonascu, Krešimir Žigić, 2005

All rights reserved. No part of this publication may be reproduced, stored in a retrieval system or transmitted in any form or by any means, electronic, mechanical or photocopying, recording, or otherwise without the prior permission of the publisher.

Published by

Charles University in Prague, Center for Economic Research and Graduate Education (CERGE) and

Economics Institute (EI), Academy of Sciences of the Czech Republic

CERGE-El, Politických vězňu 7, 11121 Prague 1, tel.: +420 224005 153, Czech Republic.

Printed by CERGE-EI, Prague

Subscription: CERGE-El homepage: http://www.cerge-ei.cz

Editors: Directors of CERGE and EI

Managing editors: Deputy Directors for Research of CERGE and EI

ISSN 1211-3298

ISBN 80-7343-042-8 (Univerzita Karlova v Praze, CERGE)

ISBN 80-7344-031-8 (Národohospodářský ústav AV ČR, Praha) 
CERGE-EI

P.O.BOX 882

Politických vězňů 7

11121 Praha 1

Czech Republic http://www.cerge-ei.cz 